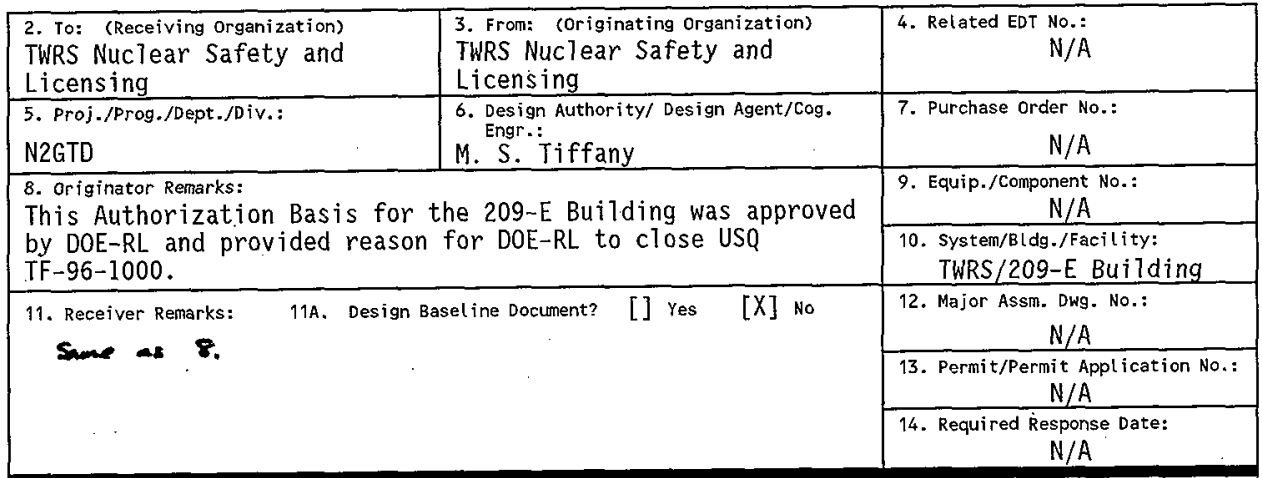

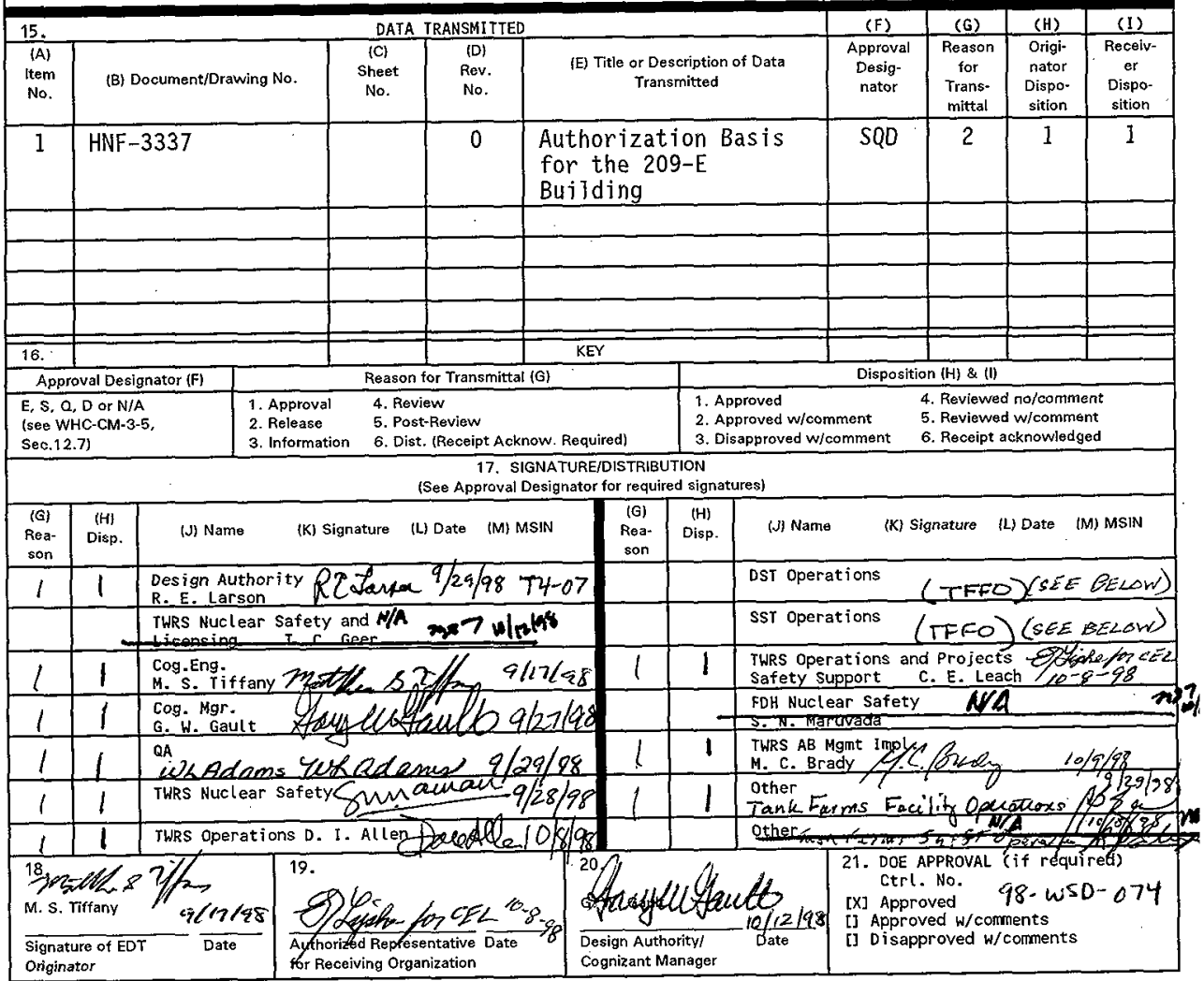

BD-7400-172-2 (05/96) GEF097 DOE/RL $R_{\text {Roming }}+2-53$ 


\title{
Authorization Basis for the 209-E Building
}

\author{
M. S. Tiffany \\ Fluor Daniel Hanford Inc., Richland, WA 99352 \\ U.S. Department of Energy Contract DE-AC06-96RL13200 \\ EDT/ECN: $\quad 625106$ \\ UC: 610 \\ Org Code: 2N400 \\ Charge Code: 101971 \\ B\&R Code: EW3120072 \\ Total Pages: 63
}

Key Words: 209-E Building, Authorization Basis, $A B$

Abstract: This Authorization Basis document is one of three documents that constitute the Authorization Basis for the 209-E Building. Per the U.S. Department of Energy, Richland Operations Office (RL) 7etter 98WSD-074, this document, the 209-E Building Preliminary Hazards Analysis (WHC-SD-WM-TI-789), and the 209-E Building Safety Evaluation Report (97WSD-074) constitute the Authorization Basis for the 209-E Building.

This Authorization Basis and the associated controls and safety programs will remain in place until safety documentation addressing deactivation of the 209-E Building is developed by the contractor and approved by RL.

TRADEMARK DISCLAIMER. Reference herein to any specific commercial product, process, or service by trade name, trademark, manufacturer, or otherwise, does not necessarily constitute or imply its endorsement, recommendation, or favoring by the United States Government or any agency thereof or $i$ ts contractors or subcontractors.

Printed in the United States of America. To obtain copies of this document, contact: Document Control Services, P.0. Box 950, Mailstop H6-08, Richland WA 99352, Phone (509) 372-2420; Fax (509) 376-4989.
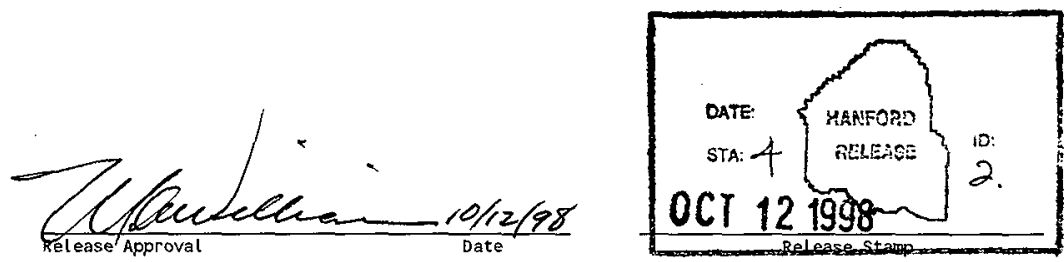

Approved for Public Release 
HNF-3337, Rev. 0

Table of Contents

Authorization Basis for the 209-E Building

1.0 PURPOSE

2.0 SCOPE

3.0 DEFINITIONS . . . . . . . . . . . . . . . . . . . . . . . 2

3.1 OPERABLE/OPERABILITY ................. . . . 2

3.2 IMMEDIATELY . . . . . . . . . . . . . . . . . . 2

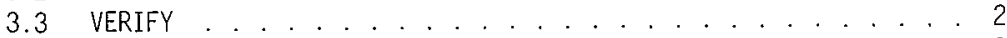

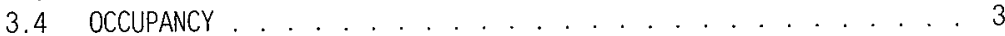

4.0 DESCRIPTION OF THE UNREVIEWED SAFETY QUESTION AND ASSOCIATED BACKGROUND

5.0 FACILITY DESCRIPTION ......................... 4

5.1 Facility Condition ................. . . 4

5.2 Facility Structure and Layout ............... 5

5.2.1 CAR Description ............. . . 5

5.2.2 Mix Room Description ............ . . 6

5.2 .3 Change Room . . . . . . . . . . . . . . . . 7

5.2 .4 Office Space . . . . . . . . . . . . . . . . 7

5.2 .5 Equipment Room . . . . . . . . . . . . . . . 7

5.3 Mechanical Systems . . . . . . . . . . . . . . . 7

5.3.1 Exhaust Ventilation System .......... . 7

5.3.2 Air Purge System . . . . . . . . . . . . . . . . . . 8

5.3.3 Fire Suppression System . . . . . . . . . . . . 8

5.3.4 209-E Bui 7 ding Tanks and Tank Contamination Status . . . 8

6.0 HAZAROS AND INITIATING EVENTS . . . . . . . . . . . . . . 10

6.1 Unfiltered Release ................... 11

6.1 .1 Loss of Ventilation . . . . . . . . . . . . . . 11

6.1.2 HEPA Filter Failure . . . . . . . . . . . . . . . . 13

6.2 Inadvertent Criticality . . . . . . . . . . . . . . . . 15

6.3 Inadvertent Fire System Actuation . . . . . . . . . . . . . . 15

6.4 fire .................. . . . . . . . . . . . .

6.4.1 Fire in the Critical Assembly Room . . . . . . . . 16

6.4.2 Fire in the Mix Room ....... . . . . . . . . . . 18

6.5 Collapse of Drain Tank (TK-111) . . . . . . . . . . . . 18

6.6 Collapse of Facility . . . . . . . . . . . . . . . 19

6.7 Tank Release ................... . . . 20 
HNF -3337 Rev. 0

Table of Contents

209-E Building Authorization Basis (cont.)

6.8 Tank Explosion .................. . . . 20

6.8.1 Runaway Chemical Reactions . . . . . . . . . . . . . . . 20

6.8.2 Hydrogen Generation and Subsequent Combustion . . . . . 21

7.0 AUTHORIZATION BASIS DOCUMENTATION MODIFICATIONS . . . . . . . . 21

8.0 ACTIVITIES . . . . . . . . . . . . . . . . . . . . 22

8.1 Authorized Activities . . . . . . . . . . . . . . . . . . 22

8.1.1 Maintenance Activities............ . . 22

8.1.2 Surveillance . . . . . . . . . . . . . . . . 23

8.1.3 Occupancy . . . . . . . . . . . . . . . 23

8.2 Activities NOT Authorized . . . . . . . . . . . . . . . . 24

8.2.1 Ignition Sources . . . . . . . . . . . . . . . 24

8.2 .2 Fissile Material . . . . . . . . . . . . . . 24

8.2.3 Facility Deactivation . . . . . . . . . . . . . 24

9.0 SAFETY MANAGEMENT AND PROGRAMS APPLICABLE TO THE 209-E BUILDING: . . 25

9.1 Radiological Protection . . . . . . . . . . . . . . . 25

9.2 Fire Protection Program . . . . . . . . . . . . . . . . . . . 26

9.3 Work Control . . . . . . . . . . . . . . . . . . . . . . . 27

9.4 Emergency Preparedness . . . . . . . . . . . . . . . . . . . . 27

9.5 Radioactive and Hazardous Waste Management . . . . . . . . . . 29

9.6 Testing, Surveillance, and Maintenance . . . . . . . . . . . . 29

9.7 Conduct of Operations . . . . . . . . . . . . . . . . . . . . . . . . . . . . . . 29

9.8 Training and Procedures . . . . . . . . . . . . . . . . . . . . 29

9.9 Quality Assurance . . . . . . . . . . . . . . . . . . . . . . . 30

9.10 Configuration Management . . . . . . . . . . . . . . . . . . . 30

9.11 Occurrence Reporting . . . . . . . . . . . . . . . . . . . . . . 30

9.12 Unreviewed Safety Questions . . . . . . . . . . . . . . . . . 30

9.13 Human Factors . . . . . . . . . . . . . . . . . . . . 30

10.0 ADMINISTRATIVE CONTROL (AC) FOR HEPA FILTER NOMINAL PARTICULATE REMOVAL

EFFICIENCY . . . . . . . . . . . . . . . . . . . 31

10.1 Requirement for HEPA Filter Control . . . . . . . . . . . 31

10.2 Program Key Elements . . . . . . . . . . . . . . . . . . 31 
HNF-3337, Rev. 0

Table of Contents

Authorization Basis for the 209-E Building (cont.)

11.0 LIMITING CONDITIONS FOR OPERATION (LCOS) FOR HYDROGEN ACCUMULATION AT THE 209-E BUILDING . . . . . . . . . . . . . . . . . 32

11.1 Air Purge System Controls . . . . . . . . . . . . . . . . . . 32

11.2 Exhaust Ventilation System Controls . . . . . . . . . . . 37

12.0 SAFETY SYSTEMS, STRUCTURES, AND COMPONENTS AND SAFETY SUPPORT SYSTEMS

13.0 RESIDUAL RISK FROM CONDITIONS, OPERATIONS AND ACTIVITIES AT THE 209-E BUILDING . . . . . . . . . . . . . . . . . . . . 41

14.0 PROCESS TO IMPROVE THE TWRS AUTHORIZATION BASIS WITH RESPECT TO THE USQ

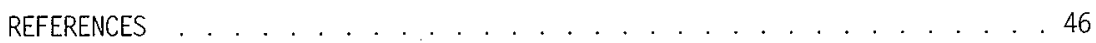

APPENDIX A . . . . . . . . . . . . . . . . . . . 49

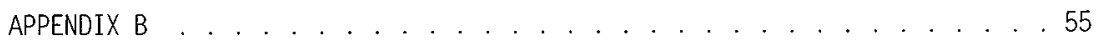




\section{HNF-3337, Rev. 0}

\section{List of Figures}

Figure 1. General Locations of Various Structures Near the 209-E Building 43

Figure 2. Generat Layout of the 209-E Building . . . . . . . . . . . 44

Figure 3. 209-E Building Exhaust Ventilation System .......... 45 


\section{AUTHORIZATION BASIS FOR THE 209-E BUILDING}

\subsection{PURPOSE:}

The purpose of this document is to establish an interim Authorization Basis for the 209-E Building for its pre-deactivation condition. This document defines the activities allowed along with controls and safety programs to be implemented and in part, replaces U.S. Department of Energy, Richland Office (RL) letter 97-WSD-160 (DOE 1997) as the facility Authorization Basis. The controls and safety programs are based on the hazards identified in the Preliminary Hazards Analysis (FDHI 1996) in addition to supplemental information obtained through recent facility evolutions (e.g., entries into the Critical Assembly Room (CAR) and Mix Room, vapor sampling of TK-111, management walk downs). Per RL letter 98-WSD-074 (DOE 1998), this document, the Preliminary Hazards Analysis (PHA), and the 209-E Building Safety Evaluation Report (DOE 1998) constitute the Authorization Basis for the 209-E Building. This Authorization Basis and the associated controls and safety programs will remain in place until safety documentation addressing deactivation of the 209-E Building is developed by the contractor and approved by RL.

\subsection{SCOPE:}

This Authorization Basis applies only to the 209-E Building and associated equipment. The operation of the 90-Day Resource Conservation and Recovery Act (RCRA) of 1976 waste storage pad, adjacent to the 209-E Building, is not part of this Authorization Basis but is addressed within the Tank Waste Remediation System (TWRS) Basis for Interim Operation (FDHI 1997a). Additional structures are in the proximity of the 209-E Building and are also not within the scope of this Authorization Basis. These structures include: 1) the Hot Semi-Works Building, to the east of the 209-E Building, 2) Building 2718, operated by Pacific Northwest National Laboratory (PNNL), located to the southwest of the 209-E Building, and 3) office trailer M0-434, located to the northeast of the 209-E Building. Figure 1 shows the locations of the various structures with respect to the 209-E Building. Impacts to these structures posed by the 209-E Building and impacts to the 209-E Building posed by these structures are addressed in Section 6.0 . 


\section{HNF-3337, Rev. 0}

\subsection{DEFINITIONS:}

\section{I OPERABLE/OPERABILITY}

A system, subsystem, train, component, or device sha11 be OPERABLE or have OPERABILITY when it is capable of performing its specified safety function(s), and (a) setpoints are within limits. (b) operating parameters necessary for OPERABILITY are within limits, and (c) when a 11 necessary attendant instrumentation, controls, electrical power, cooling or seal water, lubrication, or other auxiliary equipment that are required for the system, subsystem, train, component, or device to perform its safety function(s) are also capable of performing their related safety support function(s).

(DOE 5480.22) - annotated

\subsection{IMMEDIATELY}

A time of IMMEDIATELY means that the required action is to be commenced without delay, and continuously pursued in a controlled manner until complete. The use of IMMEDIATELY implies the highest sense of urgency. Implementation of IMMEDIATELY shall be given top priority over all other activities.

As a TWRS facility, any action at the 209-E Building requiring a response of IMMEDIATELY sha11 be given priority over other TWRS activities not requiring IMMEDIATE responses.

\subsection{VERIFY}

A qualitative assessment to confirm or substantiate that specific plant conditions exist. This may include collecting sample data or quantitative data; taking instrument readings; recording data and information on logs, data sheets, or electronic media; and evaluating data and information according to procedures. 


\section{HNF-3337, Rev. 0}

\subsection{OCCUPANCY}

OCCUPANCY is the routine access of portions of the 209-E Building other than the CAR and Mix Room for purposes of supporting the 90-day RCRA waste storage pad operations.

\subsection{DESCRIPTION OF THE UNREVIEWED SAFETY QUESTION AND ASSOCIATED BACKGROUND:}

In October of 1996, an Unreviewed Safety Question (USQ) screening/determination (DESH 1996) was performed that reviewed replacing a High Efficiency Particulate Air (HEPA) filter in the exhaust ventilation system of the 209-E Building. The USQ process led to the discovery that the facility did not have an Authorization Basis. Subsequent review of documentation identified that the facility contains 562 grams of Plutonium (conservative total based on both $\mathrm{Pu}^{239}$ and $\mathrm{Pu}^{240}$ from a plutonium inventory performed in 1990). Additionally, a Criticality Safety Evaluation Report (WHC 1990) concluded that a criticality is not credible. Since a criticality is not credible and the facility contains more than $450 \mathrm{~g}$ of plutonium, the facility is considered a Hazard Category 3 facility per DOE-STD-1027 (DOE 1992a). This categorization designates the 209-E Building as a nuclear facility and therefore requires that the facility have an Authorization Basis per DOE Order 5480.23 (DOE 1992b). A USQ was declared due to the existence of a nuclear facility without an Authorization Basis.

Shortly after discovering that no Authorization Basis existed for the 209-E Building, the contractor's Radiological Control organization imposed controls as a precautionary measure for personnel safety. Since there were unknowns associated with the facility, these controls were intended to remain in place unt $i 1$ the hazards were addressed and the issue of not having an Authorization Basis was resolved. A PHA was performed to determine the hazards associated with the facility. The PHA is a qualitative analysis based on the knowledge and expertise of individuals familiar with the facility. It should be noted that the precautionary controls initially implemented on the premise of unknowns. were carried over into an interim Authorization Basis for the 209-E Building. This Authorization Basis (DOE 1997) was issued August 8, 1997 and was implemented at a time when there were still unknowns associated with the facility (e.g. . extent of contamination in the CAR and Mix Room, configuration and operability of SSCS as identified in DOE 1997). Information was subsequently obtained during recent entries into the CAR and Mix Room for purposes of assessing hazards. and implementation of the 
interim controls of DOE 1997. Additional information was obtained through vapor sampling activities on the drain tank (TK-111). The PHA and the subsequently obtained physical data and observations provide justification to depart from many of the interim Authorization Basis controls that were originally imposed as precautionary measures due to unknowns associated with the facility.

\subsection{FACILITY DESCRIPTION:}

\subsection{Facility Condition}

The 209-E Building is located in the 200 East area of the Hanford Nuclear Reservation. The facility was constructed in 1960 and was designed such that quantities of plutonium or uranium in solution could be brought into critical configurations under careful7y controlled and monitored conditions. In the late 1980's. Pacific Northwest Laboratory (PNL) was "directed by DOE to prepare the facility for unmanned status by December 31, 1988" (PNL 1989a). The preparation for shut-down is documented to have included: 1) removal of all bulk fissile material, 2) identification of any process tanks that contain enough residual fissile material to require flushing, 3) flushing applicable tanks with condensate to remove residual fissile materia1, 4) packaging and removal of the condensate following the addition of an absorbent, 5) verifying the tanks were empty and ventilated, 6) performing a Non-Destructive Analysis (NDA) to determine quantities of any remaining fissile material, where possible (i.e., vessel not embedded in concrete). 7) stabilizing contamination to the extent possible in the glove boxes and fume hoods (i.e., wiping), and 8) performing modifications and maintenance on the fire systems (e.g., blowing dry system lines out, adding heaters for wet pipe systems in areas of potential freezing). These items were documented as completed in the status report (PNL 1989a), prior to facility turn-over from PNL to the Westinghouse Hanford Company in 1989. The recent entries into the CAR and Mix Room along with vapor sampling of the drain tank (TK-111) have provided confidence that these listed activities and conditions described in the status report are accurate. 


\subsection{Facility Structure and Layout}

The 209-E Building (Figure 2) is an L-shaped reinforced concrete structure that includes offices, a control room, shops, an Equipment Room, a change room, the Mix Room, and the Critical Assembly Room (CAR). The rooms that contain contaminated equipment and material include the CAR, the Mix Room, and the "hot side" of the change room. These three rooms are the onty Radiological Areas at the 209-E Building and were the ones primarily addressed in the PHA.

\subsubsection{CAR Description}

Criticality experiments were conducted in the CAR, which contains two reactor hoods where the critical assemblies were held. Each hood has its own HEPA filter and instrumentation that was monitored from the control room. Contaminated equipment located in the CAR includes four hood assemblies and thirteen tanks, ranging from $35 \mathrm{~L}$ ( $10 \mathrm{gal}$ ) to $400 \mathrm{~L}$ (106 gal). The CAR is posted in accordance with (WHC 1995a) and maintained locked. Access is controlled through the Facility Manager. Recent entries identified trace amounts of alpha contamination (less than $20 \mathrm{dpm} / 100 \mathrm{~cm}^{2}$. Which is less than detectable by hand held equipment) on the surfaces of the CAR. The radiological data that was obtained can be found in the Radiological Survey Report (LMHC 1997b). Three localized alpha contamination spots were identified, the highest being 46 $\mathrm{dpm} / 100 \mathrm{~cm}^{2}$. No beta or gamma radiation was detected. Additional alpha contamination exists within the exhaust ventilation system, as may be reasonably expected. The north, east, and west wal1s of the CAR are $1.5 \mathrm{~m}(5 \mathrm{ft})$ thick, while the south wall is $1 \mathrm{~m}$ ( $3 \mathrm{ft}$ ) thick. Both the ceiling and floor are $0.6 \mathrm{~m}(2 \mathrm{ft})$ thick. A $0.8 \mathrm{~m}(2.5 \mathrm{ft})$ thick motor-operated door is located on the south side of the CAR. The 209-E Building structure was designed to provide both shielding from radiation and strength to withstand pressures generated from potential uncontrolled criticalities (GE 1960).

Habitability was assessed by the Industrial Health and Safety organization and documented in LMHC 1997C. It was 
determined that there is sufficient oxygen in the CAR and Mix Room for habitability. Additionally, it was determined that there are no toxicological concentrations (LMHC 1997C) that warrant either supplied air or air purifying respiration for personnel entry into the CAR or Mix Room. There are no toxicological sources identified within the CAR that can change the toxicological conditions.

\subsubsection{Mix Room Description}

The Mix Room provided the necessary facilities for receiving, handling, and preparing the various types and forms of radionuclides and chemicals used in the experiments. This room is also ventilated with the exhaust ventilation system that ventilates the CAR. Like the CAR, the Mix Room contains contaminated equipment including three hood assemblies, and nine tanks, ranging from $10 \mathrm{~L}$ ( 3 ga 1 ) to $320 \mathrm{~L}(85 \mathrm{gal})$. The Mix Room is posted in accordance with (WHC 1995a) and maintained locked. Access is controlled through the Facility Manager. Recent entries identified minimal amounts of alpha contamination on the surfaces of the Mix Room. The radiological data that was obtained can be found in the Radiological Survey Report (LMHC 1997b). Generally, the contamination was found to be less than $20 \mathrm{dpm} / 100 \mathrm{~cm}^{2}$ with the exception of one localized smearable contamination spot that was found to be 367 $\mathrm{dpm} / 100 \mathrm{~cm}^{2}$.

Habitability was assessed by the Industrial Health and Safety organization and documented in LMHC 1997C. It was determined that there is sufficient oxygen in the CAR and Mix Room for habitability. Additionally. it was determined that there are no toxicological concentrations (LMHC 1997C) that warrant either supplied air or air purifying respiration for personnel entry into the CAR or Mix Room. There are no toxicological sources identified within the Mix Room that can change the toxicological conditions. 


\subsubsection{Change Room}

The "cold" side of the Change Room is located adjacent to the Mix Room. The "hot" side of the Change Room is located in the passage way between the Mix Room and CAR. Together, both sides of the Change Room enable personnel access to the CAR and Mix Room per radiological procedures (WHC 1995a).

\subsubsection{Office Space}

The office space of the 209-E Building includes offices, rest rooms, and a lunch room. These locations support the operations of the 209-E 90-day storage pad and waste packaging operations.

\subsubsection{Equipment Room}

The Equipment Room contains the air compressors for the air purge and CAR fire system, chemical product storage cabinets, and the electrical breakers that supply power to the 209-E Building.

\subsection{Mechanical Systems}

\subsubsection{Exhaust Venti]ation System}

The CAR and Mix Room are ventilated with an active ventilation system. A damper in the inlet ventilation duct has been locked in the closed position, forcing ventilation to be supplied through infiltration only. The exhaust ventilation system consists of fire-resistant HEPA filters, an exhaust fan, and a stack. Power is supplied to the fan via a breaker in the Equipment Room. The damper on the exhaust fan was secured in the open position to allow a ventilation pathway in case of a ventilation failure. See Figure 3 for the general layout of the exhaust ventilation system. 


\subsubsection{Air Purge System}

Air is supplied to the twelve process tanks (see Section 5.3.4) via an air purge system. The purge air exits the tanks through tubing tied into the exhaust ventilation system. The air purge system consists of tubing, air compressors, pressure reducing valves, and flow indicating controllers (i.e., rotameters). The pressure reducing valves limit the supply pressure of the air to $35 \mathrm{psig.}$ The air purge flow rate to each tank is measured and adjusted by a flow indicating controller. Flow is measured by the position of a bead as seen through a graduated glass tube with a range between $0.2 \mathrm{scfh}$ and $2 \mathrm{scfh}$. Flow is adjusted by a needle valve at the base of the flow indicating controller. The flow indicating controllers are affixed to instrumentation racks located in the CAR and Mix Room. Purge air flow can only be verified by entering the CAR and Mix Room.

\subsubsection{Fire Suppression System}

Fire protection for the CAR is provided by a pre-action sprinkler system, meaning the system remains dry and pressurized with air. Pressurization with air achieves freeze protection during cold weather. If a fire were to occur in the CAR, heat activated devices would actuate a valve, pressurizing the fire suppression system with water. The air compressors that supply air to the purge system. also supply air to the fire suppression system.

Unlike the CAR, the Mix Room has a wet pipe system, meaning that it is continuously pressurized with water. The fire suppression system for the rest of the 209-E Building also uses raw water and is continuously pressurized.

\subsubsection{9-E Building Tanks and Tank Contamination Status}

The following tank information was compiled from PNL 1987 and PNL 1989a. There were twe lve process tanks that were used for solution handling. These tanks include TK-101. 
TK-102, TK-103, TK-104, TK-105, TK-106, located in the CAR and TK-213. TK-231, TK-232, TK-233, TK-234, and TK-235, located in the Mix Room. Per the status report, these tanks were flushed, are tied into the exhaust ventilation system. and have an air purge system to remove any generated hydrogen.

Another tank. TK-111, was used as a drain tank and is located underground, adjacent to the south end of the facility. This passively ventilated tank was sampled routinely, where it was determined that plutonium levels were below limits for discharging the contents to a crib. A recent vapor sample of the drain tank (TK-111) identified no detectable flammable gas within the tank (FDHI 1997C).

One tank. TK-108, contained water and not process solution; it is open to room atmosphere, is located in the CAR, and is considered flushed since it only contained water.

The experimental vessels, TK-141, TK-161, and TK-162, have a bottom drain and are vented to the exhaust ventilation system for hydrogen removal. These tanks are all located in the CAR. As stated in the status report. TK-141 was thoroughly flushed. The status report states that an NDA was performed to provide "before" plutonium quantities (i.e., baseline indications prior to decontamination efforts). This was used as a guide to perform limited decontamination on certain experimental vessels. TK-161 and TK-162, each assayed by NDA to contain $4 \mathrm{~g}$ of plutonium, fell into this realm.

Tank TK-206 was used for calibration and load out of solutions and is located in the Mix Room. The tank was flushed prior to facility turnover as indicated in the status report.

Two tanks, TK-215 and TK-216, were used as process condensate catch tanks, are vented, and are considered flushed since they only contained condensate. These tanks are located in the Mix Room.

Lastly, tanks TK-109 and TK-110 are designated as dump tanks and were designed to preclude criticalities at expected 
plutonium concentrations. The dump tanks' function was to receive the experiment solution, ending the experiment when desired or if the neutron flux became too high. The $35 \mathrm{~L}$ (10 gal) dump tanks are located in concrete two feet underneath the CAR reactor hoods. TK-109 is known to have received process solutions, was flushed and is vented by the exhaust ventilation system. There is no knowledge that TK-110 was ever used. A tabulated tank summary is included in Appendix A.

\subsection{HAZARDS AND INITIATING EVENTS:}

This section provides the tabulated hazards and initiating events, as identified in the PHA. The same basic methodology used for the TWRS BIO was used for identifying needed controls and programs. This methodology identifies and addresses those hazards from the PHA that: 1) are credible and have the potential for offsite or onsite consequences, or 2) have a frequency of "Anticipated" and have potential consequences to the facility worker. An assessment is provided for each hazard. outlining any required controls or safety programs to prevent or mitigate the consequences of the PHA identified hazards. Since there were unknowns during preparation of the PHA, subsequent information supersedes information from the PHA, where overlapping. These instances are noted in this section of this Authorization Basis document.

The possibility of a runaway chemical reaction resulting in a tank explosion hazard is addressed within Appendix $B$ and is based on the status report, process knowledge, and conversations with personnel involved with the criticality experiments. Since runaway chemical reaction hazards have the potential for a tank explosion resulting in potential material release, it is addressed in the same section as hydrogen generation and subsequent combustion. The May 1997 tank explosion at the Hanford Plutonium Reclamation Facility (not associated with the 209-E Building), was the driver to closely assess chemical vulnerabilities (i.e., potential for runaway chemical reactions) at other Hanford facilities. Because the incident followed the completion of the PHA. this particular type of vulnerability was not specifically identified or discussed in the hazards tables of the PHA.

Impacts of nearby facilities' operations/hazards on the 209-E Building have not been formally documented through a hazards analysis process. However, with the exception of the Hot Semi-Works Building, hazards 


\section{HNF-3337, Rev. 0}

imposed on the 209-E Building by the other facilities and areas listed in Section 2.0 have been addressed through the TWRS BIO Emergency Response Program (FDHI 1997a). Implementation of the emergency responses to the hazards imposed by these facilities on the 209-E Building is through FDHI 1998b. as required by Section 9.4. Any hazards that may be imposed by the Hot Semi-Works Building on the 209-E Building, have not been addressed.

\subsection{Unfiltered Release}

\subsubsection{Loss of Ventilation}

A loss of ventilation and all of its initiators (e.g., loss of power, inadvertent fan shutdown, mechanical failure of fan) were assessed a frequency of "Anticipated" with potential consequences to the facility worker. It is postulated that loose contamination or hazardous materials would migrate to the clean side of the building upon loss of ventilation. This qualitative assessment was made during preparation of the PHA and was based on unknown radiological conditions within the CAR and Mix Room. Recent entries into the CAR and Mix Room have yielded a better understanding of the extent of the contamination present in the rooms.

An additional initiating event for loss of ventilation was postulated following the development of the PHA. This initiating event involves a vehicle collision with the ventilation system equipment that is located on a concrete pad at the south side of the 209-E Building. Such an event is qualitatively assessed a frequency of "Unlikely" with potential consequences to the facility worker. In the event of a collision, any damage that might occur would involve the ducting. HEPA filter housing, or fan itself. If the ducting is damaged such that a hole is created and the fan is still operating. the fan would draw clean air through the hole and release it to the atmosphere after filtration. No release of material to the onsite receptor would occur but the effectiveness of the ventilation system to draw from the 209-E Building would be reduced. This is the same as the loss of ventilation scenario. Similarly, a loss of ventilation would occur if the fan is impacted in the collision and becomes non-operational. Therefore, two 
initiators of a loss of ventilation; a hole in the ducting and failure of the fan, are assessed within this section and appropriate programs are outiined. If the HEPA filter housing is damaged, the filter would not sit properly in the housing. This is the same as an improperly installed or improperly seated HEPA filter and is addressed in Section 6.1.2.

\section{Assessment:}

The contractor Radiological Control organization has determined that the extent of the surface contamination within the CAR and Mix Room is minimal. Contamination is assumed to be located within the ventilation duct work and is known to exist in the reactor hoods and process tanks. Per Section 8.2, removal of permanent equipment or altering fissile content is not allowed, minimizing the potential release of additional material into the CAR and Mix Room. Therefore, barring an accidental release, the radiological conditions will not change while the 209-E Building Authorization Basis is in place. This is confirmed by radiological surveys performed within the occupied areas and at the boundaries of the radiological areas to continually assess the radiological conditions of the facility. This assessment is performed in accordance with the Hanford Site Radiological Control Manual, HSRCM-1 (WHC 1995a). Because a loss of ventilation has the potential to result in consequences to the facility worker, a program is required for Radiological Control. This program is briefly described in Section 9.1, Radiological Protection, and is the same as the existing program cited in the TWRS BI0. An additional program is required to ensure appropriate responses are taken in the event of an emergency. This program is briefly described in Section 9.4. Emergency Preparedness, and is integral to the existing program cited in the TWRS BIO.

The vehicle collision with the ventilation equipment has potential consequences to the facility worker because it could be postulated to result in a loss of ventilation. A vehicle collision with the ventilation equipment is qualitatively assessed a frequency of "Unlikely" because the area near the ventilation equipment is not typically accessed by motorized vehicles (e.g.. automobiles, trucks, 
forklifts, etc.). Motorized vehicle access is minimal because the 209-E Building parking area and surrounding roadway is not a major thoroughfare. Further, the ventilation equipment is large and readily noticeable and is well in view by personnel who have occasion to occupy the 209-E Building area via motorized vehicle.

The contractor Industrial Health and Safety organization has assessed the toxicological conditions of the CAR and Mix Room. It was determined that there were no toxicological concentrations that warranted either supplied air or air purifying respiration for personnel entry into these rooms. There are no toxicological sources identified within the CAR and Mix Room that can change the toxicological conditions. Therefore, it is concluded that toxicological consequences are adequately addressed by the Emergency Preparedness and Work Control programs briefly described in Sections 9.4 and 9.3, respectively.

\subsubsection{HEPA Filter Failure}

Initiating events for an unfiltered release due to HEPA filter failure include: 1) improper filter installation, 2) filter plugging leading to blowout, 3) fire, 4) plugged filter, and 5) mechanical damage to the filter housing by a vehicle collision. Improper filter installation and filter blowout have been identified within the PHA to have potential consequences to the onsite worker and have been assessed a frequency of "Unlikely". Fires are addressed within Section 6.4 of this document, having the same consequences and frequency as out lined in that section. A plugged filter as identified in the PHA, reduces the vacuum in the facility thereby creating a scenario similar to a loss of ventilation. The plugged filter hazard has the same consequences and frequency of a loss of ventilation and is therefore addressed by Section 6.1.1 of this document. The remaining hazard, breach of HEPA filtration, is addressed here. 


\section{HNF-3337, Rev. 0}

Assessment:

A breach of HEPA filtration occurs during an improper installation, a degradation in the filter material, or mechanical damage to the filter housing. Based on the amount of material present within the duct work, reactor hoods, and process vessels, it is postulated that this hazard can result in an accident with potential onsite consequences. This scenario assumes that the hazard would contain some mechanism to dislodge radiological materials held up in the ventilation system. These materials would be released to the environment through the unfiltered path way and are qualitatively postulated to exceed risk guidelines for dose to the onsite worker. Therefore, a control is required to assess the adequacy of filter placement upon installation and periodically thereafter. This control is stated in Section 10.0 .

The vehicle collision scenario does not include a mechanism to dislodge radioactive materials held up in the process vessels or reactor hoods. The only material that is postulated to be released would be that entrained within the HEPA filters. Information that was not considered during preparation of the PHA, is an assay report (PNNL 1996) that quantified the amount of radioactive materials held within the previous HEPA filters. The assay results documented maximum radioactive material quantities within the HEPA filters to be $0.53 \mathrm{~g} \mathrm{U}^{235}$ and $0.032 \mathrm{~g}$ of Pu. Based on the assayed quantities of radioactive materials present in the filters, any release of the radioactive materials following a vehicle collision with the filter housing is not postulated to result in consequences exceeding onsite or offsite risk guidelines. This is further bolstered by the fact that there are two banks of HEPA filters as shown in Figure 3. A vehicle collision that would damage both banks of HEPA filters simultaneously is postulated to be incredible since the HEPA filter housings are located on different sides of the concrete pad. Therefore, in the event of a vehicle collision with a HEPA filter housing. one bank of HEPA filtration would remain functional. It should be noted that the PNNL assay results were based on the previous HEPA filters that had been in use for many years. The quantity of materials present on the current HEPA 


\section{HNF-3337, Rev, 0}

fitters is therefore expected to be much less than that documented by the assay results. This will remain true during the pre-deactivation period at the 209-E Building since there are no activities allowed that will dislodge additional radioactive materials. As an added defense-indepth measure, a visual barrier (i.e., rope) has been erected to alert motorized vehicle operators of the ventilation equipment.

\subsection{Inadvertent Criticality}

Inadvertent criticality was addressed in the PHA, where it was assessed a frequency of "Beyond Extremely Un7ikely". Prior to the PHA, an engineering analysis assessed the status of fissile material in the 209-E Building and documented the results in WHC 1990. Consistent with the PHA, WHC 1990 concluded that a criticality is not credible at the 209-E Building. Additionally, this facility is classified as a Limited Control Facility per Section 1.10.4 of FDHI 1997d. As a Limited Control Facility, no fissile material is allowed to be added to the facility.

\section{Assessment:}

Because an accident involving a criticality is not credible, there are no additional controls required beyond those associated with the designation of "Limited Control Facility" and the excluded activities described in Section 8.2.

\subsection{Inadvertent Fire System Actuation}

The PHA identified that freezing of the fire suppression system or a loss of compressed air with a failure of the fusible link could result in a pool of water in the CAR or Mix Room. This pool is postulated to spread contamination, resulting in potential radiological consequences to the facility worker. The hazard was assessed a frequency of "Anticipated" in the PHA.

The extent of contamination is minimal on the surfaces in the CAR and Mix Room, as identified during recent entries into the CAR and Mix Room. Additionally, the status report indicated that remaining "Pu is in vessels that have been thoroughly flushed with 
condensate, and no further Pu removal is expected unless a stronger agent is used for flushing" (PNL 1989a). Since the fire system only uses water, the post-flushing hold up of residual Pu in the tanks is not likely to be mobilized during fire system actuation. Because of this and because the surface contamination in the CAR and Mix Room is minima1, inadvertent fire system actuation would result in minimal contamination spread.

\section{Assessment:}

The spread of contamination would be minimal in case of inadvertent actuation of the fire suppression system. However. because the consequences have been qualitatively assessed in the PHA and have not been quantitatively determined, a combination of safety SSC maintenance and safety programs is required. Programs involved include Radiological Control and Emergency Response. Safety SSC maintenance is addressed in Section 8.1.1. Radiological Control and Emergency Preparedness programs are briefly described in Sections 9.1 and 9.4, respectively.

\subsection{Fire}

\subsubsection{Fire in the Critical Assembiy Room}

From the PHA, a fire occurring in the CAR, with subsequent release, is the accident that represents the highest risk. This was based on a loose combustible initiator. A consequence ana7ysis (WHC 1996a) was prepared based on the fire hazard, where it was calculated that an unmitigated fire in the CAR would result in dose consequences exceeding risk guidelines to the onsite worker. Being unmitigated. this calculation did not take credit for the building structure or HEPA filtration. It should be noted that the accident exceeded risk guidelines based on the frequency of "Anticipated". The frequency of "Anticipated" was assessed during development of the PHA, at which time it was known that there were loose combustibles and potentially flammable solvents in the CAR and Mix Room. These items have been removed, thereby eliminating the combustible initiator of the fire in the CAR hazard. The electrical fire/heater failure initiator, noted in the PHA remains, but was assigned a frequency of "Un 1 ikely". Based on the caiculated 
consequences (WHC 1996a), a fire in the CAR with a frequency of "Unlikely" does not exceed risk guidelines.

The Tank Farms Fire Hazards Analysis (WHC 1996b) identifies the possibility that the CAR and Mix Room glove boxes contain Lucite panels. The analysis identifies Lucite as a combustible material and recommends that the panels either be "removed or covered with a non-combustible material such as gypsum board". This action is not considered to be necessary during the pre-deactivation stage of the 209-E Building for four reasons: (1) the loose combustibles and potential fire initiators have been removed from the CAR and Mix Room, (2) little activity will take place in the CAR and Mix Rooms, (3) the few required activities which wi 11 take place in the CAR and Mix Room do not involve potential fire initiators, and (4) Lucite material is not a fire initiator.

\section{Assessment:}

With the removal of the loose combustibles and potentially flammable solvents from the CAR, the remaining initiator of fire in the CAR is electrical fire/heater failure. This reduces the overall fire in the CAR hazard to "Unlikely", thereby eliminating the only hazard in the PHA that could lead to consequences exceeding risk guidelines for the onsite worker. For protection of the facility worker. safety programs and maintenance of safety SSCS are available to prevent this accident from occurring. One program. Fire Protection, is briefly described in Section 9.2 and is the same as the existing program cited in the TWRS BIO. The importance of the Fire Protection Program at the 209-E Building is for facility worker safety. Another applicable program for facility worker safety is Emergency Response. and is briefly described in Section 9.4. In conclusion, the application of these safety programs is necessary for facility worker safety. Neither of these safety programs are required to ensure that risk guidelines are met for the fire in the CAR hazard. 


\section{HNF-3337, Rev. 0}

\subsubsection{Fire in the Mix Room}

The PHA assessed a fire in the Mix Room a frequency of "Un]ikely" and indicated it would have potential consequences to the onsite worker. A consequence analysis (WHC 1996a) was performed to assess the risk of a fire in the Mix Room. The consequence analysis determined that a fire in the Mix Room would be within the "Unlikely" category risk guidelines.

\section{Assessment:}

Based on the consequence analysis, it can be seen that the consequences of a fire in the Mix Room are less than those for a fire in the CAR ( $33 \mathrm{mSv}$ for the Mix Room as compared to $41 \mathrm{mSv}$ for the CAR). Based on this and because a fire in the CAR and a fire in the Mix Room were both assessed a frequency of "Unlikely", protection of facility worker for a fire in the Mix Room is addressed by the safety programs identified in Section 6.4.1

\subsection{Collapse of Drain Tank (TK-111)}

The two initiators identified within the PHA for the collapse of the drain tank hazard include: 1) a runaway fork 7 ift and 2) a seismic event. Of the two initiators, a seismic event was the most probable with an assessed frequency of "UnTikely".

\section{Assessment:}

The PHA qualitatively assessed that a collapse of the drain tank results in potential consequences to the onsite worker. Based on the past use of this tank (i.e., Pu level restrictions for crib discharge) in addition to recent measurements associated with this drain tank, it is concluded that the qualitatively estimated consequences in the PHA were overstated. The technical basis to support the conclusion that PHA consequences are overstated was documented in FDHI 1997c. Therefore, no new controls or safety programs are required to address this hazard. 


\subsection{Collapse of Facility}

The two initiators identified within the PHA for this hazard include: 1) a high wind/tornado which lifts the Mix Room roof and 2) a seismic event which causes building collapse. The high wind/tornado initiator was qualitatively assessed a frequency of "Unlikely" with potential consequences to the facility worker. Collapse of the facility due to a seismic event was postulated to result in consequences to the onsite worker and was qualitatively assessed a frequency of "Extremely Unlikely".

\section{Assessment:}

Based on the frequency of "Unlikely" and potential consequences to the facility worker. applying the methodology described in Section 6.0 results in no required controls or safety programs for the high wind/tornado initiator. However, high winds/tornados are addressed within the Building Emergency Plan as part of the Emergency Preparedness program.

Since a collapse of the facility due to a seismic event was postulated in the PHA to cause consequences to the onsite worker, safety programs are required in addition to maintenance of safety SSCS. The Hazards Summary Report (GE 1960) briefly mentions seismic events but does not identify structural calculations or discuss what magnitude of a seismic event that the facility could withstand. As described in Section 5.0, the facility was designed to withstand pressures generated from potential uncontrolled criticalities (GE 1960). GE 1960 does not quantify the pressures generated from potential uncontrolled criticalities or specify details of structural design to withstand such an event. As described in Section 12.0, the structure is a safety SSC. Minimizing the risk of facility collapse due to a seismic event relies on not allowing changes to the structure which degrade the building's resiliency to a seismic event. This minimization of risk is integral to maintaining the structure OPERABLE, and is addressed in Section 8.1.1. Seismic events are addressed as part of the Emergency Preparedness program briefly described in Section 9.4. 


\subsection{Tank Release}

Tank releases, as discussed in the PHA, result in a pool with potential consequences to the facility worker. This hazard was assessed a frequency of "Anticipated". The initiators for a tank release include: 1) degradation of the tank structure; 2) the tank tips over: and 3) a seismic event causes the tank to tip over.

\section{Assessment:}

Based on the frequency and potential consequences of a tank release, a safety program is required. An applicable program for this hazard is the Radiological Protection program as briefly described in Section 9.1. Per the program, radiological surveys of the facility are performed in accordance with WHC 1995a.

Another applicable program is the Emergency Preparedness program, briefly described in Section 9.4. As part of the program, spil1s are addressed within the FDHI 1998b.

\subsection{Tank Explosion}

A tank explosion has been identified as a hazard that presents a mechanism for radioactive material to be released, resulting in consequences to the onsite worker. Tank explosion mechanisms are discussed in detail in Appendix B, with calculations provided where applicable. The two mechanisms that were identified pertaining to tank explosions are: 1) runaway chemical reactions and 2) hydrogen generation with subsequent combustion.

\subsubsection{Runaway Chemical Reactions}

As discussed in Section 6.0, the potential for a runaway chemical reaction initiating a tank explosion was considered subsequent to the preparation of the PHA. Appendix B of. this JCO concludes that there are no chemical vulnerabilities within the tanks of the 209-E Building that could lead to a tank explosion. This conclusion was based on the types and quantities of chemicals used in the criticality experiments. 


\section{Assessment:}

Since no chemical vulnerabilities exist within the tanks of the 209-E Building, a runaway chemical reaction resulting in a tank explosion is a hazard that does not warrant controls or further consideration.

\subsubsection{Hydrogen Generation and Subsequent Combustion}

Hydrogen generation due to radiolysis of water is the other tank explosion mechanism and is one hazard identified in the PHA. The PHA assessed a frequency of "Unlikely" for hydrogen generation and subsequent combustion. Bounding calculations for hydrogen generation are provided in Appendix B.

\section{Assessment:}

Based on the frequency of "Unlikely" and the postulated consequences to the onsite worker (PHA), controls are required to prevent hydrogen accumulation. These controls are stated in Sections 11.1 and 11.2.

\subsection{AUTHORIZATION BASIS DOCUMENTATION MODIFICATIONS:}

The safety management program and controls required to manage the hazards associated with the 209-E Building are contained in this document. No changes to the TWRS BIO or Technical Safety Requirements (FDHI 1997b) are required. The citation for the approved 209-E Building Authorization Basis becomes part of the Authorization Basis list maintained in the procedure for USQS (FDHI 1997e). 
HNF -3337, Rev. 0

\subsection{ACTIVITIES:}

\subsection{Authorized Activities}

The following activities are authorized to be performed at the 209-E Building:

\subsubsection{Maintenance Activities}

The authorized maintenance activities are performed in accordance with the programs briefly described in Section 9.0 and consist of the following:

1) Pre-filter and/or HEPA filter replacement in the main Exhaust System.

2) Replacement of pre-filter and/or HEPA filters located in the CAR and Mix Room.

3) Maintenance on the fan, motor, and duct work of the exhaust ventilation system.

4) Maintenance on the air compressors in the Equipment Room.

5) Cleaning, inspection, and replacement of electrical breakers in the Equipment Room.

6) Maintenance on the fire suppression system and fire suppression system water supply, including freeze protection.

7) Maintenance related to building structural integrity.

8) Replacement of lighting to ensure controls are met and personnel safety is maintained while in the CAR and Mix Room.

9) Maintenance of equipment that has no impact on safety SSCS or safety SSC systems. 
Basis: Identifying the authorized maintenance activities ensures that: 1) the safety SSCs relied upon by the 209-E Building Authorization Basis to maintain an acceptable level of risk, remain OPERABLE, and 2) other equipment is not excluded by the 209-E Building Authorization Basis from being maintained. Per Section 12.0, the safety SSCS include the building structure, air purge system, and the exhaust ventilation system. Maintenance of other equipment is authorized if it has no impact on safety SSCs or safety SSC systems.

\subsubsection{Survei11ance}

Routine surveillance is authorized to be performed in accordance with the controls and safety programs given in Sections 9.0, 10.0, and 11.0.

Basis: This activity ensures that safety assessments are performed to minimize industrial hazards and radiological exposure.

\subsubsection{Occupancy}

The 209-E Building may continue to be occupied.

Basis: See definition of OCCUPANCY in Section 3.4. The 209-E Building occupancy supports 90-day RCRA storage pad operations and waste packaging and handling administrative functions. The controls and safety programs required by the 209-E Building Authorization Basis ensure that workers occupying the 209-E Building are afforded protection from industrial. radiological, and hazardous material safety hazards. 
HNF-3337, Rev. 0

\subsection{Activities NOT Authorized}

The following activities are NOT authorized:

\subsubsection{Ignition Sources}

Activities which could introduce an ignition source into any opening of the tanks in the CAR and Mix Room are not authorized.

Basis: Although any hydrogen in the tank vapor spaces is not expected to reach flammable concentrations, restriction of activities which could introduce sparks or ignition sources in these tanks provides extra assurance that hydrogen combustion will not occur.

\subsubsection{Fissile Material}

Any activities altering the fissile material content or configuration are not authorized.

Basis: This prevents inadvertent criticalities from occurring due to introduction of new material. Note that sma11 amounts (1ess than 150 grams, as specified in WHC 1990) of fissile material may potentially be affixed to equipment (e.g., HEPA filters) and therefore is allowed to be removed during equipment replacement. Such activities are not considered "altering the fissile content or configuration".

\subsubsection{Facility Deactivation}

Any activities removing permanent facility structures of the CAR and Mix Room such as tanks, hoods, piping, etc. are not authorized.

Basis: These activities are not authorized to occur until safety documentation addressing deactivation of the 209-E Building has been approved by RL. This 
prevents radiological conditions from changing. thus preventing the occurrence of a hazard that has not been considered.

\subsection{SAFETY MANAGEMENT AND PROGRAMS APPLICABLE TO THE 209-E BUILDING:}

Chapter 4 of the TWRS BI0 describes overa11 TWRS programmatic safety. Specific aspects of particular importance for the 209-E Building are discussed below.

\subsection{Radiological Protection}

The Radiological Protection program for the 209-E Building provides for the protection of the worker during normal operations. The worker protection program is comprised of the following elements:

- As low as reasonably achievable (ALARA) goals

- Radiation worker training

- Radiation exposure control

- Radiological monitoring

- General employee radiation training

Radiological protection activities at the Hanford Site implement the requirements of 10 CFR 835 (CFR 1993), "Occupational Radiation Protection," as directed by WHC 1995a, through sitewide programs identified in the following documents:

- HSRCM-1, Hanford Site Radiological Control Manual

- HNF-IP-0718, Hea7th Physics Procedures

- HNF-IP-0842. TWRS Administration

- WHC-IP-1043. WHC Occupationa7 ALARA Program

- HNF-SP-1145. FDH Radiation Protection Program Implementation of Title 10 Code of Federa7 Regulations Part 835

The contractor Radiological Control organization administers the Radiological Protection program. This organization also establishes radiological protection standards and procedures: 
provides independent review and evaluation of the program; conducts radiological and dosimetry support; develops and implements training; and coordinates the ALARA Program.

Basis: The Radiological Protection program is achieved through existing TWRS and Hanford sitewide procedures. These procedures are in place to ensure radiation protection of personnel. This program is the same as the existing safety management program in the TWRS BIO.

\subsection{Fire Protection Program}

The contractor Fire Protection program is established to meet the requirements of DOE Order 5480.7A (DOE 1993). Fire Protection. The program uses fire detection and extinguishing systems and equipment, administrative controls, procedures, and trained personnel to meet the requirements of DOE Order 5480.7A. Three principles are followed to prevent and mitigate the consequences of potential fires at the 209-E Building:

- Control of ignition sources and combustible and flammable materials

- Employee Training

- $\quad$ Prompt detection and suppression of fires through a combination of installed fire protection systems and a professional fire fighting organization.

The TWRS fire protection program is implemented through the Project Hanford Fire Protection procedures.

Basis: This program is the same as the existing safety management program cited in the TWRS BI0. It is in place to minimize potential onsite exposure to radiological hazards as identified in the PHA resulting from a fire within the 209-E Building. 
HNF-3337, Rev. 0

\subsection{Work Control}

Maintenance activities shall be controlled through a formal work control program. The work control program ensures the following:

- The work scope is fulty defined

- The hazards associated with the work are identified and evaluated

- Sufficient controls, based on the hazards, are identified and implemented to ensure that the work can be performed safely

- The work is executed safely and the completed work is verified

Management of work activities within TWRS is defined in HNF-IP-0842, Vol. V, Maintenance/Production Control (FDHI 1997f). TWRS Safety is addressed in HNF-IP-0842, Vo7. IX. Safety (FDHI 1997g).

Basis: This program is the same as the existing safety management program cited in the TWRS BIO. Work management helps identify hazards on the job to ensure that work is performed safely. Note that the Unreviewed Safety Question process is integral to the Work Control program and ensures that proposed activities are within the approved Authorization Basis.

\subsection{Emergency Preparedness}

The TWRS Emergency Preparedness program establishes planning, procedures, and training programs to effectively prepare for. manage, and respond to emergencies and incidents affecting the health and safety of the worker and public. As part of TWRS, emergency response at the 209-E Building has been addressed by a section of the Tank Farms Building Emergency Plan. The Emergency Preparedness program implements the DOE 5500 series orders. 


\section{HNF-3337, Rev. 0}

The TWRS Emergency Plan currently includes descriptions of the following:

- Response organizations, authorities, responsibilities, and relationship with the technical support center and emergency operations facility established for emergency response

- Actions to be taken with state and local agencies for responses to events that involve the potential for a release of radiological materials

- $\quad$ Emergency classification system and associated emergency action levels

- Notification processes and the associated communications systems

- Methods, systems, and equipment available for assessing actua 1 or potential emergency conditions

- $\quad$ Protective actions required to provide maximum protection to workers and the public

- Medical resources available to assist in the event of an emergency

- Technical assessment and mitigation of facility emergency conditions

- Requirements for providing information to the public, offsite authorities, and local media

- $\quad$ Emergency facilities and equipment avaitable to support emergency operations

- $\quad$ Staffing and training needs of the Emergency Response Organization

- Drills and exercises required to develop. maintain, and test the response capabilities of the Emergency Response Organization 
HNF-3337, Rev. 0

TWRS Emergency Preparedness program at the 209-E Building is implemented through the following procedures:

- HNF-IP-0263-209E, 209-E Faci7ity Building Emergency Plan

- HNF-IP-0971, Tank Waste Remediation System (TWRS) Emergency Preparedness Program Plan

Basis: This program is the same as the existing safety management program cited in the TWRS BIO. Emergency preparedness establishes procedures detailing actions to be taken during emergency situations. The 209-E Building Emergency Plan includes the necessary responses to be taken for events such as spil1s, fires, and loss of utilities (e.g., loss of ventilation).

\subsection{Radioactive and Hazardous Waste Management}

The 209-E, Building is a TWRS facility. Therefore, refer to Section 4.6 of FDHI 1997a for the Radioactive and Hazardous Waste Management program.

9.6 Testing, Survei11ance, and Maintenance

The 209-E Building is a TWRS facility. Therefore, refer to Section 4.7 of FDHI 1997a for the Testing. Surveillance, and Maintenance program.

\subsection{Conduct of Operations}

The 209-E Building is a TWRS facility. Therefore, refer to Section 4.8 of FDHI 1997a for the Conduct of Operations program.

\subsection{Training and Procedures}

The 209-E Building is a TWRS facility. Therefore, refer to Section 4.11 of FOHI 1997a for the Training and Procedures program. 


\section{HNF-3337, Rev. 0}

\subsection{Quality Assurance}

The 209-E Building is a TWRS facility. Therefore, refer to Section 4.12 of FDHI 1997a for the Quality Assurance program.

\subsection{Configuration Management}

The 209-E Building is a TWRS facility. Therefore, refer to Section 4.15 of FDHI 1997a for the Configuration Management program.

\subsection{Occurrence Reporting}

The 209-E Building is a TWRS facility. Therefore, refer to Section 4.16 of FDHI 1997a for the Occurrence Reporting program.

\subsection{Unreviewed Safety Questions}

The 209-E Building is a TWRS facility. Therefore, refer to Section 4.17 of FDHI 1997a for the Unreviewed Safety question program.

\subsection{Human Factors}

The 209-E Building is a TWRS facility. Therefore, refer to Section 4.18 of FDHI 1997a for the Human Factors program. 
HNF-3337, Rev. 0

10.0 ADMINISTRATIVE CONTROL (AC) FOR HEPA FILTER NOMINAL PARTICULATE REMOVAL EFFICIENCY :

10.1 Requirement for HEPA Filter Control

A program shall be maintained to ensure the capability of HEPA filters to mitigate the potential consequences of the accident scenarios.

\subsection{Program Key Elements}

VERIFY HEPA filter nominal particulate removal efficiency is $\geq 99.95 \%$ by performance of an aerosol test with the design air flow through the filter, according to the guidance in American Society of Mechanical Engineers (ASME) N510. Testing of Nuclear Air Treatment Systems and Energy Research and Development Administration (ERDA) 76-21, Nuclear Air Cleaning Handbook.

Perform the aerosol test after installation and every 12 months thereafter.

If HEPA filter efficiency does not meet the required $99.95 \%$, shut down the exhaust ventilation system IMMEDIATELY and restore efficiency prior to restoring ventilation.

Basis:

The use of HEPA filters at the required efficiency enables facilities to meet DOE criteria for normal ventilation effluents. Aerosol testing is an administrative feature credited in the PHA to prevent a potential release to the environment and radiation exposure to facility and on-site workers. This control is consistent with that of Administrative Control 5.18, item $c$ of FDHI 1997a for HEPA filter efficiency.

Shutting down the ventilation system requires voluntary entry into the Actions of LCO 11.2. Thus, the time required to restore the efficiency of the HEPA filters is dependent on the Completion Times required by LCO 11.2. 
HNF-3337, Rev. 0

11.0 LIMITING CONDITIONS FOR OPERATION (LCOS) FOR HYOROGEN ACCUMULATION AT THE 209-E BUILDING:

11.1 Air Purge System Controls

LCO 11.1 The air purge on the twelve solution handling tanks (TK-101, TK-102, TK-103, TK-104, TK-105, TK-106, TK-213, TK-231, TK-232, TK-233, TK-234, TK-235) sha1] be OPERABLE.

ACTIONS

\begin{tabular}{|c|c|c|c|}
\hline & CONDITION & REQUIRED ACTIONS & $\begin{array}{c}\text { COMPLETION } \\
\text { TIME }\end{array}$ \\
\hline A. & $\begin{array}{l}\text { Air purge } \\
\text { system } \\
\text { inoperable. }\end{array}$ & $\begin{array}{ll}\text { A.1 } & \text { Restore the air } \\
& \text { purge system to } \\
& \text { OPERABLE status. }\end{array}$ & 25 days \\
\hline B. & $\begin{array}{l}\text { Required Action } \\
\text { and associated } \\
\text { Completion Time } \\
\text { of Condition A } \\
\text { not met. }\end{array}$ & $\begin{array}{l}\text { B.1. } \\
\text { a. Submit a Recovery } \\
\text { Plan to RL for } \\
\text { information, and } \\
\text { b. Restore the air } \\
\text { purge system to } \\
\text { OPERABLE status. }\end{array}$ & $\begin{array}{l}\text { a. IMMEDIATELY } \\
\text { b. } 70 \text { days }\end{array}$ \\
\hline
\end{tabular}

SURVEILLANCE REQUIREMENTS

\begin{tabular}{ll|l}
\multicolumn{1}{c|}{ SURVEILLANCE } & FREQUENCY \\
\hline \hline SR 11.1 & $\begin{array}{l}\text { VERIFY the air purge system is } \\
\text { OPERABLE }\end{array}$ & 90 days \\
\hline \hline
\end{tabular}


BACKGROUND When the 209-E Building was prepared for shut-down status, trace amounts of plutonium were unable to be flushed and remain in the solution handling tanks. The status report indicates that a smal1 heel of water also might remain in the tanks. Therefore, hydrogen generation is possible within these tanks through radiolysis of any remaining water.

It has been postulated during RL review that OPERABLE status of the air purge system might be affected if there is a mechanism for the air exit path to be blocked, such as the presence of crystals formed during solution storage and handling. Since air purge verification history has not been established, it is not known if this condition exists within the tanks. Iff, for any reason, the exhaust air path is blocked, the tanks will build up pressure until a pressure equilibrium is reached with that of the air purge system. This will result in a no flow situation and will eventually be identified via the flow indicating controllers during air purge flow verifications. A no flow situation would not meet the OPERABLE requirement of this control and restoration of flow would be required per the Required Actions. Having no flow during the 90 day period will not result in any tank exceeding $25 \%$ of the LFL. This is because it has been calculated that 115 days is required to reach $25 \%$ of the LFL, as discussed in Appendix B.

APPLICABLE SAFETY ANALYSIS
The PHA identifies hydrogen generation and subsequent combustion as a hazard. Per the PHA and status report, ignition sources are limited. The PHA qualitatively assessed that hydrogen generation with subsequent combustion has the potential for consequences to the onsite worker. 
APPLICABLE

SAFETY

ANALYSIS

(cont.)
No quantitative assessment has been provided for the hydrogen generation and subsequent combustion hazard.

Bounding calculations (Appendix B) show that it would take 115 days to achieve $25 \%$ of the LFL for hydrogen assuming no air purge or active ventilation. Appendix $B$ calculations a7so show that an air purge flow rate of $0.00216 \mathrm{~L} / \mathrm{min}$ $\left(0.00458 \mathrm{ft}^{3} / \mathrm{hr}\right)$ is required for each tank to prevent hydrogen concentrations from reaching $25 \%$ of the LFL.

The requirement for the air purge system to be OPERABLE has been specified to minimize the accumulation of flammable gas by providing air flow through the tank vapor space.

The air purge system is OPERABLE when there is indication of flow within the operating range of the individual tank flow indicating controllers. Since the flow indicating controllers have an operating range between 0.2 scfh and 2 scfh, OPERABLE status ensures that an air purge rate of at least $0.2 \mathrm{scfh}$ is achieved. As calculated in Appendix $B, 0.00458 \mathrm{ft}^{3} / \mathrm{hr}$ is required to maintain the vapor space below $25 \%$ of the LFL. As can be seen, an air purge rate of 0.2 scfh is sufficient to purge any hydrogen that is generated at a rate of $0.00458 \mathrm{ft}^{3} / \mathrm{hr}$.

In the worst case scenario, purge air flow is lost right after the 90 day surveillance and is not discovered until the next surveillance (i.e.. 90 days later). In this case, the calculations in 
ACTIONS

(cont.)
Appendix $B$ indicate that 25 days (i.e., 115 days minus 90 days) could elapse before $25 \%$ of the LFL for hydrogen is reached if restoration has not occurred. Therefore, it is seen that a hazardous condition does not develop instantaneously, even in the worst case loss of flow scenario.

\section{B.1}

The recovery plan describes the steps necessary to restore the system to OPERABLE status. Approval of the recovery plan is obtained from the Project Hanford Management Contract Director of Tank Farm Operations. Once approved, the recovery plan is submitted to RL-TWRS Director, Waste Storage Division, for information.

The 70 day completion time results from a conservative approach based on allowance to accumulate up to $40 \%$ of the LFL during the recovery phase of the action statements. This assumes that the air purge system becomes inoperable immediately after the surveillance is performed (i.e. . 185 days to reach $40 \%$ of the LFL consisting of a possible 90 day maximum surveillance period and 25 days allowed action period). The $40 \%$ is chosen as providing a margin of safety.
SURVEILLANCE REQUIREMENTS
Verification that the air purge system is OPERABLE is performed every 90 days. More frequent surveillance is not prohibited. Appendix B calculations identify that it would take 115 days to reach $25 \%$ of the LFL for hydrogen. Therefore. verifying that the air purge system is OPERABLE at a survei 77 ance frequency of 90 days ensures that the vapor space composition is maintained at less than $25 \%$ of the LFL for hydrogen. 
HNF-3337, Rev. 0

SURVEILLANCE REQUIREMENTS (cont.)
The air purge Flow Indicating Controllers (FICs) at the 209-E Building are of a fixed type (i.e., designed and ordered from the manufacturer to be between 0.2 and 2 standard cubic feet per hour $(s c F h)$ and are not able to be calibrated. Even though the air purge flow is a required function. not being able to calibrate the FICs does not pose a problem because: 1) any verification of flow on scale is at least 2000 times greater than the required flow, 2) the calculation for hydrogen generation was based on conservative assumptions, and 3) any error in the flow measurement is on the conservative side (e.g., increased friction due to scaling within the graduated tube requires more air flow to obtain the same reading, etc.). False readings (i.e., bead stuck in graduation tube) might occur in a no flow situation. This situation is identified during air purge verification through needle valve adjustment and visual identification of bead movement. 
HNF-3337, Rev. 0

\subsection{Exhaust Ventilation System Controls}

LCO 11.2 The exhaust ventilation system sha11 be OPERABLE.

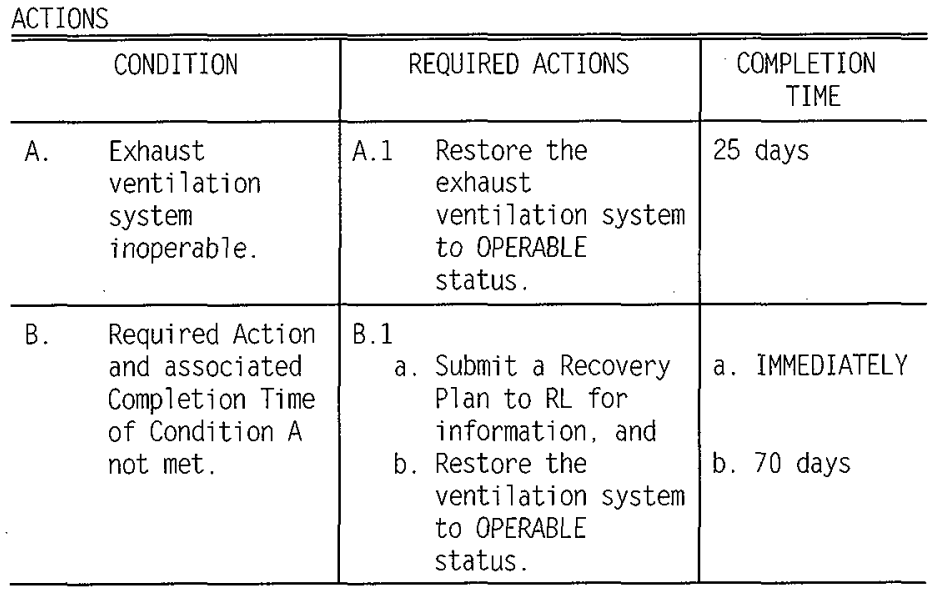

SURVEILLANCE REQUIREMENTS

\begin{tabular}{ll|l}
\hline \hline \multicolumn{1}{c|}{ SURVEILLANCE } & FREQUENCY \\
\hline SR 11.2 & $\begin{array}{l}\text { VERIFY the exhaust ventilation } \\
\text { system is OPERABLE }\end{array}$ & 90 days \\
\hline \hline
\end{tabular}


BACKGROUND When the 209-E Building was prepared for shut-down status, trace amounts of plutonium were unable to be flushed and remain in the solution handiing tanks. The status report indicates that a small heel of water also might remain in the tanks. Therefore, hydrogen generation is possible within these tanks through radiolysis of any remaining water.

Only twelve of the twenty-two 209-E Building tanks are serviced by the air purge system. Therefore, the exhaust ventilation system is required to be OPERABLE to remove any accumulated hydrogen from the remaining nine tanks within the 209-E Building. The only non-applicable tank is the drain tank. TK-111, which is passively ventilated and is located outside of the 209-E Building.

APPLICABLE SAFETY ANALYSIS
The PHA identifies hydrogen generation and subsequent combustion as a hazard. Per the PHA and status report, ignition sources are limited. The PHA qualitatively assessed that hydrogen generation with subsequent combustion has the potential for consequences to the onsite worker. No quantitative assessment has been provided for the hydrogen generation and subsequent combustion hazard.

The air purge system services those tanks which are considered to pose the greatest risk in terms of hydrogen generation. The remaining nine tanks, which vent to the room atmosphere or to the exhaust ventilation system. contain less material capable of hydrogen generation. As documented in Appendix $B$, the air flow required to vent these nine tanks is $0.00216 \mathrm{~L} / \mathrm{min}\left(0.00458 \mathrm{ft}^{3} / \mathrm{hr}\right)$ per tank. Therefore, the safety function provided by the ventilation system is readily met by the 
HNF-3337, Rev. 0

APPLICABLE ventilation systern design (i.e., nominal

SAFETY $\quad 1,000 \mathrm{cfm}$ ).

ANALYSIS

(cont.)

LCO

The requirement for the exhaust ventilation system to be OPERABLE has been specified to minimize the accumulation of $f 7$ ammable gas.

Verification that the exhaust ventilation system is OPERABLE consists of verifying that the ventilation system is operating and is performed via: 1) visual confirmation of the exhaust indicating light located in the Equipment Room and, 2) audible detection at the fan.

As a defense-in-depth measure, flow measurements are taken biannually on the exhaust ventilation system. The flow measurements verify ventilation system operability by ensuring flow exists within the exhaust ventilation system.

ACTIONS

A. 1

In the worst case scenario. exhaust ventilation is lost right after the 90 day surveillance and is not discovered until the next surveillance (i.e., 90 days later). In this case, the calculations in Appendix 8 indicate that 25 days (i.e. 115 days minus 90 days) could elapse before $25 \%$ of the LFL for hydrogen is reached if restoration has not occurred. Therefore, it is seen that a hazardous condition does not develop instantaneously, even in the worst case loss of flow scenario. 
ACTIONS

(cont.)
B.1

The recovery plan describes the steps necessary to restore the system to OPERABLE status. Approval of the recovery plan is obtained from the Project Hanford Management Contract Director of Tank Farm Operations. Once approved, the recovery plan is submitted to RL-TWRS Director, Waste Storage Division, for information.

The 70 day completion time results from a conservative approach based on allowance to accumulate up to $40 \%$ of the LFL during the recovery phase of the action statements. This assumes that the air purge system becomes inoperable immediately after the surveillance is performed (i.e., 185 days to reach $40 \%$ of the LFL consisting of a possible 90 day maximum surveillance period and 25 days allowed action period). The $40 \%$ is chosen as providing a margin of safety.
SURVEILLANCE REQUIREMENTS
Verification that the exhaust ventilation system is OPERABLE is performed every 90 days. More frequent surveillance is not prohibited. Appendix $B$ calculations identify that it would take 115 days to reach $25 \%$ of the LFL for hydrogen. Therefore, verifying the exhaust ventilation system is OPERABLE at a surveillance frequency of 90 days ensures that the vapor space composition is maintained at less than $25 \%$ of the LFL for hydrogen. 
HNF-3337, Rev, 0

12.0 SAFETY SYSTEMS. STRUCTURES. AND COMPONENTS AND SAFETY SUPPORT SYSTEMS:

The following equipment is identified as safety systems, structures and components:

- 209-E Building structure

- Fire suppression freeze protection system

- Process tank air purge system (including air compressors)

- Exhaust ventilation system

Basis: The equipment is designated as safety Systems. Structures, and Components due to the mitigative and preventive features that the equipment provides. The safety SSCs are all associated with hazards that result in potential consequences to the onsite worker or "Anticipated" consequences to the facility worker. Per Section 8.1.1, these systems shall be maintained to perform their intended safety functions.

13.0 RESIDUAL RISK FROM CONDITIONS. OPERATIONS AND ACTIVITIES AT THE 209-E BUILOING:

Risks are minimized by the following factors: 1) combustibles and waste drums have been removed from the CAR and Mix Room, 2) surface

contamination in the CAR and Mix Room is minimal, 3) safety measures for facility shut-down, as documented in the status report, have been validated by observation and measurement, 4) any activity which could mobilize residual contamination is prohibited during

pre-deactivation. 5) no new fissile material will be introduced into the facility, 6) habitability for purposes of pre-deactivation activities in the CAR and Mix Room have been confirmed by radiological and industria? hygiene surveys, 7) preventive controls have been specified for the two credible accident scenarios (i.e., hydrogen accumulation and ignition. and breach of HEPA filtration), and 8) the 209-E Building is part of TWRS and benefits from the safety programs required by the TWRS Authorization Basis.

A11 of these factors give a high degree of confidence that there are no significant risks to the facility worker in the 209-E Building.

Further. there are no significant risks for release of radiological or toxicological materials to the onsite worker or the public as a result of authorized activities or postulated accidents at the 209-E Building. 
HNF-3337, Rev. 0

14.0 PROCESS TO IMPROVE THE TWRS AUTHORIZATION BASIS WITH RESPECT TO THE USO:

RL closed the 209-E Building USQ as stated in DOE 1998. This Authorization Basis document has been approved by RL, providing an Authorization Basis for the 209-E Building that has been derived from a thorough identification and consideration of potential hazards. An Authorization Basis amendment for deactivation of the 209-E Bui 7 ding wi11 eventually replace the 209-E Building Authorization Basis, once approved by RL. 
Figure 1. General Locations of Various Structures Near the 209-E Building

7th Stroet

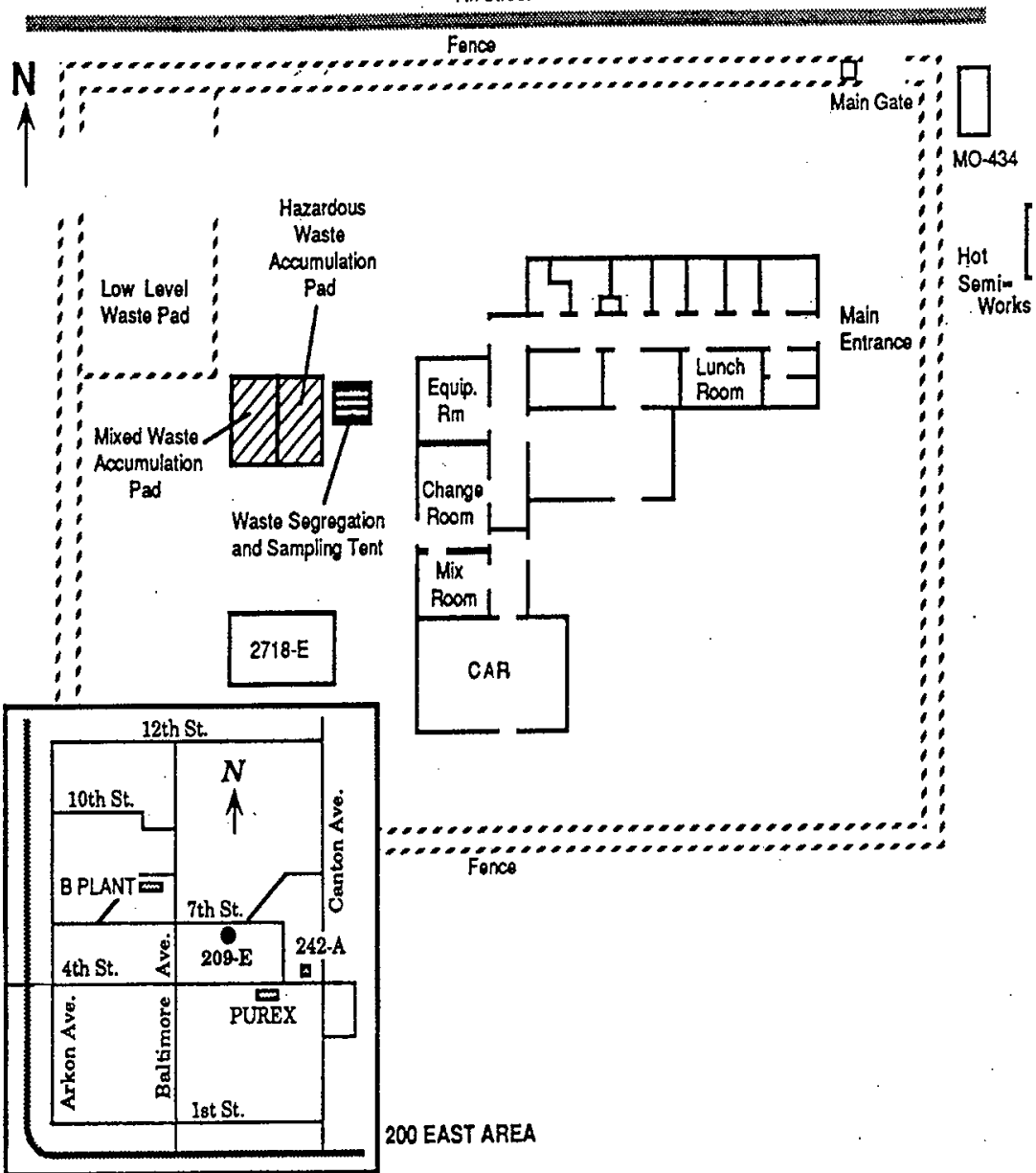


HNF-3337, Rev. 0

Figure 2. General Layout of the 209-E Building
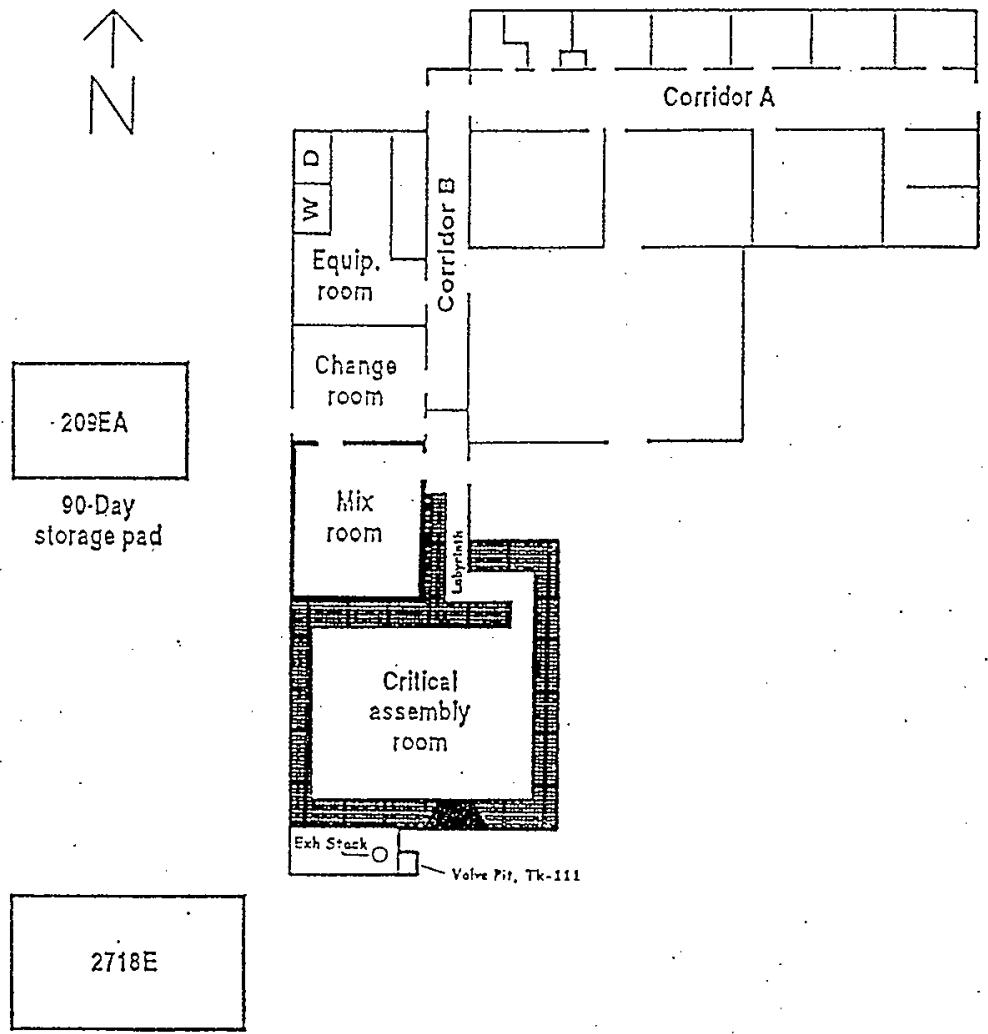

Intermediate holding pad 
Figure 3. 209-E Building Exhaust Ventilation System

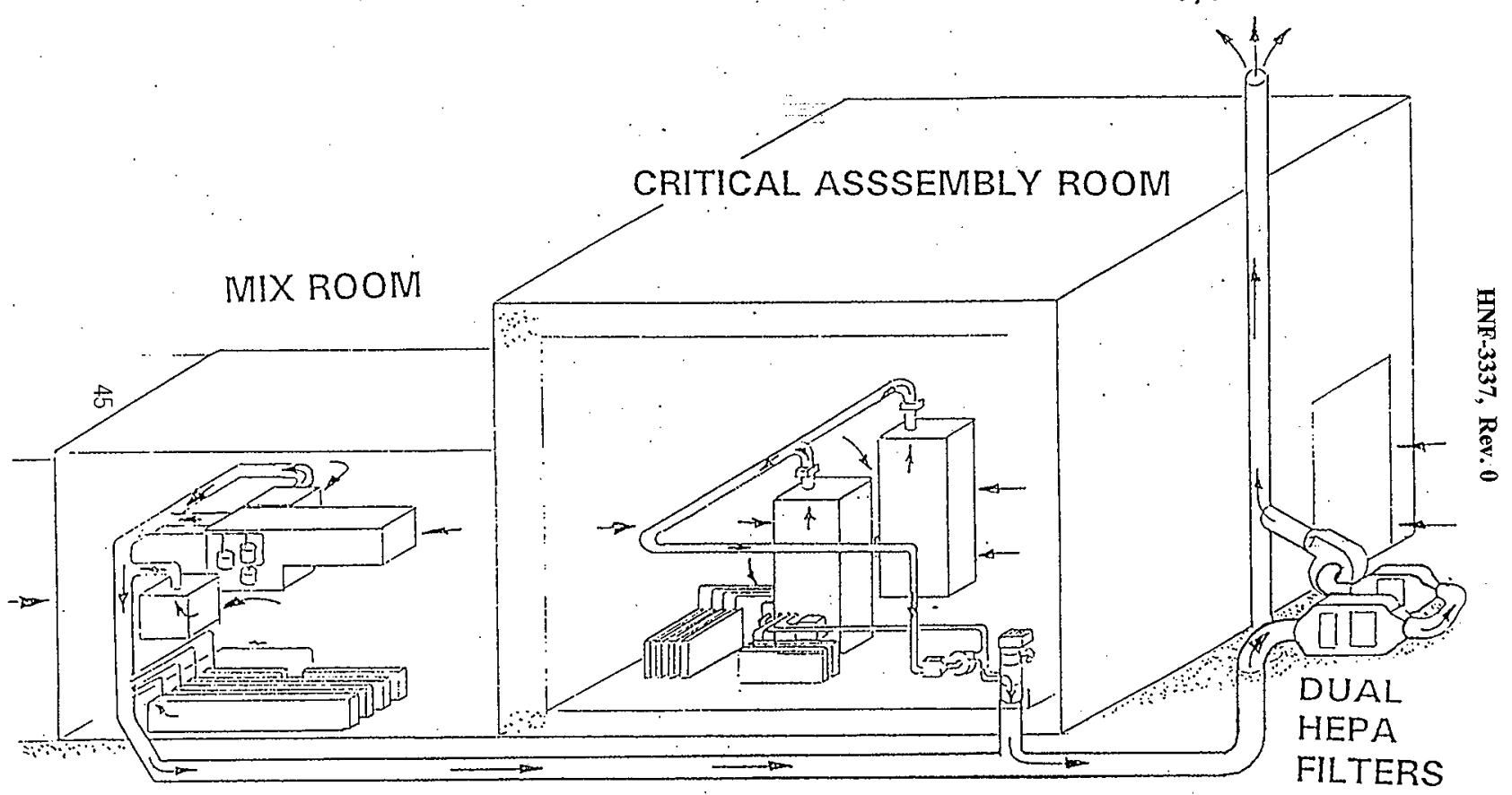

AIR SUPPLY IS BY IN-LEAKAGE 
HNF-3337, Rev. 0

REFERENCES

CFR 1993. Occupational Radiation Protection, 10 CFR 835, Code of Federa1 Regulations

DESH 1996, Unreviewed Safety Question; HEPA Filter Change at the 209-E Facility, TF-96-1000, Rev. 0, Duke Engineering and Services Hanford

DOE 1998, Contract Number DE-AC06-96RL13200 - Approva7 of Justification for Continued Operation (JCO) for 209-E Building, 98-WSD-074, 9757083A. Department of Energy, Richland Office

DOE 1997, Contract Number DE-AC06-96RL13200 - Declaration of 209-E Unreviewed Safety Question for Deficient Authorization Basis and Institution of Interim Contro7s, 97-WSD-160, 9757083A, Department of Energy, Richland office

DOE 1993, Fire Protection, DOE Order 5480.7A, U. S. Department of Energy

DOE 1992a. Hazard Categorization and Accident Analysis Techniques for Compliance with DOE Order 5480.23. Nuclear Safety Analysis Reports. DOE-STD-1027-92, U.S. Department of Energy

DOE 1992b, Nuclear Safety Analysis, DOE Order 5480.23, U. S. Department of Energy

DOE 1992c, Technical Safety Requirements, DOE Order 5480.22, U. S. Department of Energy

FDHI 1998a. Tank Waste Remediation System (TWRS) Emergency Preparedness Program P7an. HNF-IP-0971, Fluor-Daniel Hanford Inc.

FDHI 1998b, 209-E Facility Building Emergency P7an, HNF-IP-0263-209E, Fluor Daniel Hanford Inc.

FDHI 1997a. Tank Waste Remediation System Basis for Interim Operation, HNF-SD-WM-BIO-001, Rev 0-G. Fluor Daniel Hanford Inc.

FDHI 1997b. Tank Waste Remediation System Technical Safety Requirements, HNF-SD-WM-TSR-006, Rev 0-I. Fluor Daniel Hanford Inc. 
REFERENCES (cont.)

FDHI 1997c, Contract Number DE-AC06-96RL13200; Information Regarding Unreviewed Safety Question Screening/Determination TF-97-0869;

Occurrence Report - 209-E Solution Hand7ing Tank Purge Air Requirements, FDH-9760653. Fluor DanieT Hanford Inc.

FDHI 1997d, Criticality Safety General, Requirements, HNF-PRO-334, Fluor Daniel Hanford Inc.

FOHI 1997e, Unreviewed Safety Questions, HNF-IP-0842, Vol. IV, Section 5.4, Rev. 10g. Fluor Daniel Hanford Inc.

FDHI 1997f. Maintenance/Production Control, HNF-IP-0842, Vol. V. Fluor Daniel Hanford Inc.

FDHI 1997g, Safety, HNF-IP-0842, Vol. IX, Fluor Daniel Hanford Inc.

FDHI 1997h, FDH Radiation Protection Program Implementation of Tit7e 10 Code of Federa7 Regulations Part 835. HNF-SP-1145. Fluor Daniel Hanford Inc.

FDHI 1997i, Health Physics Procedures, HNF-IP-0718, Fluor Daniel Hanford Inc.

FDHI 1996, Preliminary Hazards Analysis - 209-E Building - Critical Mass Laboratory. WHC-SD-WM-TI-789, Rev. 0. Fluor Daniel Hanford Inc.

GE 1960, Hazards Sumary Report for the Hanford Plutonium Critical Mass Laboratory, HW-66266, General Electric

LMHC 1997a, Calculation of Hydrogen Release Rate at Steady State for DoubleShe17 Tanks. HNF-SD-WM-CN-117; Rev. 0, Lockheed Martin Hanford Corporation

LMHC 1997b. Radiological Survey Report, W309924, Lockheed Martin Hanford Corporation

LMHC 1997c. Hanford Industrial Hygiene Database, Survey \# 97-1252, Lockheed Martin Hanford Corporation

PNNL 1996, PNNL Box Assayer Results, R. J. Arthur, June 5, 1996, Pacific Northwest National Laboratories 
HNF-3337, Rev. 0

REFERENCES (cont.)

PNL 1989a, Status Report for Hanford's Critical Mass Laboratory, [no document number issued]. Pacific Northwest Laboratories

PNL 1989b, Resu7ts of Hold-up Measurement at 209-E; internal letter of H. H. VanTuy 1 dated January 27, 1989. Pacific Northwest Laboratories

PNL 1987. Safety Evaluation Document for the Critica7 Mass Laboratory Project 0-370 Modifications. Pacific Northwest Laboratories

WHC 1996a, Consequence Analysis of Two Postulated Fires in the 209-E Building. WHC-SD-WM-CN-083, Rev. 0, Westinghouse Hanford Company

WHC 1996b, Tank Farms Fire Hazards Ana7ysis, WHC-SD-WM-FHA-020, Westinghouse Hanford Company

WHC 1995a, Hanford Site Radiological Control Manual, HSRCM-1, Rev. 2, Westinghouse Hanford Company

WHC 1995b, WHC Occupationa7 ALARA Program, WHC-IP-1043, Westinghouse Hanford Company

WHC 1990. CSER 90-008: Reclassification of the Critical Mass Laboratory, Building 209-E As a Limited Control Facility. WHC-SD-SQA-CSA-20326. Rev. 0. Westinghouse Hanford Company 


\section{APPENDIX A}

\section{9-E Tank Status}

This report summarizes the best available information, to date, regarding the contents, and status of the tanks within the 209-E Building (both the CAR and the Mix Room). This information is based on material contained in the Status Report for Hanford's Critical Mass Laboratory (PNL 1989a).

Supplemental information was obtained during a meeting (July 1997) with Mr. Harold VanTuyl, scientist and former manager of the 209-E Building at the time of turnover of the facility from PNL to WHC in 1989. In the table below. "Verified as empty" means that the tanks were flushed to remove as much plutonium as possible. Residual plutonium exists in some tanks as noted in the table below.

There is a total of 22 tanks at the facility as follows:

$\notin$

\section{Critical Assembly Room:}

\begin{tabular}{|c|c|c|c|c|c|c|}
\hline Tank \# & Capacity & Contents & Flushed & Vented & Summary Fron cited Sources & Brawing \# \\
\hline 101 & $330 \mathrm{~L}$ & $1 \mathrm{gPu}$ & Y & Y & $\begin{array}{l}\text { Critically safe slab tank used as a } \\
\text { Condensate Storage Tank. Verified as being } \\
\text { empty and purged with air to evaporate } \\
\text { liquid. }\end{array}$ & $\begin{array}{c}H-2-96021, \text { Rev } 2 \text {, } \\
\text { Sht } 1\end{array}$ \\
\hline 102 & $330 \mathrm{~L}$ & $\begin{array}{c}\text { Residual } \\
U\end{array}$ & Y & Y & $\begin{array}{l}\text { Critically safe slab tank used as a U } \\
\text { Solution Storage Tank. Verified as being } \\
\text { empty and purged with air to evaporate } \\
\text { liquid. }\end{array}$ & $\begin{array}{c}\text { H-2-96021, Rev } 2 \\
\text { Sht } 1\end{array}$ \\
\hline
\end{tabular}




\begin{tabular}{|c|c|c|c|c|c|c|}
\hline Tank \# & Capacity & Contents & Flushed & Vented & 1.2 Summary From cited Sources & Brawing \# \\
\hline 103 & $290 \mathrm{~L}$ & $8 \mathrm{~g} \mathrm{Pu}$ & Y & Y & $\begin{array}{l}\text { Critically safe slab tank used as a Pu } \\
\text { Solution Storage Tank. Verified as being } \\
\text { empty and purged with air to evaporate } \\
\text { liquid. }\end{array}$ & $\begin{array}{c}H-2-96022, \operatorname{Rev} 2 . \\
\text { Sht } 1\end{array}$ \\
\hline 104 & $290 \mathrm{~L}$ & $15 \mathrm{~g} \mathrm{Pu}$ & Y & Y & $\begin{array}{l}\text { Critically safe slab tank used as a Pu } \\
\text { Solution Storage Tank. Verified as being } \\
\text { empty and purged with air to evaporate } \\
\text { liquid. }\end{array}$ & $\begin{array}{c}H-2-96022, \text { Rev } 2 \\
\text { Sht } 1\end{array}$ \\
\hline & $400 \mathrm{~L}$ & $38 \mathrm{~g} \mathrm{Pu}$ & Y & $\gamma$ & $\begin{array}{l}\text { Critically safe slab tank used as a Pu } \\
\text { Solution Storage Tank. Also served as a } \\
\text { dump tank for experimental vessels. } \\
\text { Verified as being empty and purged with air } \\
\text { to evaporate liquid. }\end{array}$ & $\begin{array}{c}\text { H-2-96019. } \operatorname{Rev} 2 \\
\text { Sht } 1\end{array}$ \\
\hline 106 & $400 \mathrm{~L}$ & $123 \mathrm{~g} \mathrm{Pu}$ & $\gamma$ & $\gamma$ & $\begin{array}{l}\text { Critically safe slab tank used as a Pu } \\
\text { Solution Storage Tank. Also served as the } \\
\text { feed/mix tank and dump tank for } \\
\text { experimental vessels. Verified as being } \\
\text { empty and purged with air to evaporate } \\
\text { liquid. }\end{array}$ & $\begin{array}{c}\text { H-2-96019, Rev } 2 \\
\text { Sht } 1\end{array}$ \\
\hline 108 & $\begin{array}{l}11,735 \\
L \\
(3,100 \\
\text { gal })\end{array}$ & --- & N/A & $\begin{array}{l}\text { N/A - } \\
\text { open } \\
\text { to } \\
\text { atm. }\end{array}$ & $\begin{array}{l}\text { Fuel Element Assembly System is open at the } \\
\text { top and contained water, not process } \\
\text { solution. }\end{array}$ & $\begin{array}{c}\text { H-2-96014, Rev } 2 \text {, } \\
\text { Sht } 1\end{array}$ \\
\hline
\end{tabular}




\begin{tabular}{|c|c|c|c|c|c|c|}
\hline Tank \# & Capacity & Contents & Mushed & Vented & Summary Trom Ctted Sources & Drawing \# \\
\hline 109 & $35 \mathrm{~L}$ & --- & $-\cdots$ & $\begin{array}{c}y-\text { no } \\
\text { inlet }\end{array}$ & $\begin{array}{l}\text { Critically safe slab tank used as the dump } \\
\text { tank for solutions used in experimental } \\
\text { vessels tested in H0-140. Located } 2 \mathrm{ft} \text {. } \\
\text { beneath the floor ( } 2 \mathrm{ft} \text {. thick concrete) } \\
\text { under H0-140. Covered with a cadmium } \\
\text { sheet, laminated polyethylene and set in } \\
\text { concrete. Went out of service pre-1984 and } \\
\text { is capped off. }\end{array}$ & $\begin{array}{c}\text { HW-66266 } \\
\text { Fig 7: } \\
\text { H-2-96016, Rev 2. } \\
\text { Sht 1 }\end{array}$ \\
\hline 110 & $35 \mathrm{~L}$ & -- & -- & N & $\begin{array}{l}\text { This tank is a sister tank to } 109 \text {, and } \\
\text { there was piping between the two. It is } \\
\text { similarly located beneath the floor under } \\
\text { Ho-170. Information on status identified } \\
\text { on page } 10 \text { of Status Report. Went out of } \\
\text { service pre-1984. }\end{array}$ & $\begin{array}{c}\text { HW-66266 } \\
\text { Fig } 7 \text {; } \\
\text { H-2-96015, Rev 2. } \\
\text { Sht } 1\end{array}$ \\
\hline 111 & $189 \mathrm{~L}$ & $-\cdots$ & Y & $\begin{array}{c}\gamma- \\
\text { passiv } \\
e\end{array}$ & $\begin{array}{l}\text { Critically safe slab tank used as a waste } \\
\text { hold-up tank. Located } 4 \mathrm{ft} \text {. beneath the } \\
\text { ground level, adjacent to the south door of } \\
\text { the CAR outside of the building. Covered } \\
\text { with a cadmium sheet, laminated } \\
\text { polyethylene and set in concrete. Contained } \\
\text { low level Pu prior to being dumped to crib. } \\
\text { was sampled and fell below limit } \\
\text { requirements before crib transfer per } \\
\text { documentation on file. }\end{array}$ & $\begin{array}{c}\text { HW-66266 } \\
\text { Fig 7; } \\
\text { H-2-96014, Rev 2. } \\
\text { Sht } 1\end{array}$ \\
\hline
\end{tabular}




\begin{tabular}{|c|c|c|c|c|c|c|}
\hline Tank \# & Capacity & Contents & lushed & Vented & Summary F rom Gited Sources. & Brawing \#. \\
\hline 141 & -- & $36 \mathrm{~g} \mathrm{Pu}$ & Yes & $\left|\begin{array}{c}\gamma-\text { no } \\
\text { inlet }\end{array}\right|$ & $\begin{array}{l}\text { Experimental vessel with a bottom drain. } \\
\text { Called the Bellows Tank because of its } \\
\text { expandable slab tank design. Tank is one } \\
\text { of many reactor assemblies used in } \\
\text { conducting criticality experiments in the } \\
\text { CAR. Test solutions were pumped into the } \\
\text { assemblies for experiments and pumped back } \\
\text { to the solution handling system when } \\
\text { testing was complete. }\end{array}$ & $\begin{array}{c}\text { H-2-96016, Rev } 2 \\
\text { Sht } 1\end{array}$ \\
\hline 161 & $\cdots$ & $4 \mathrm{gPu}$ & No & $\begin{array}{c}Y-\text { no } \\
\text { inlet }\end{array}$ & $\begin{array}{l}\text { Experimental vessel with bottom drain. } \\
\text { Critical experiments were conducted in the } \\
\text { tank using procedure similar to that } \\
\text { described for tank } 141 .\end{array}$ & $\begin{array}{c}\text { H-2-96017, Rev 2, } \\
\text { Sht } 1\end{array}$ \\
\hline 162 & $\ldots$ & $4 \mathrm{gPu}$ & No & $\mid \begin{array}{c}Y-\text { no } \\
\text { inlet }\end{array}$ & $\begin{array}{l}\text { Experimental vessel with bottom drain. } \\
\text { Critical experiments were conducted in the } \\
\text { tank using procedure similar to that } \\
\text { described for tank } 141 \text {. }\end{array}$ & $\begin{array}{c}\text { H-2-96017, Rev } 2 \text {, } \\
\text { Sht } 1\end{array}$ \\
\hline
\end{tabular}




\begin{tabular}{|c|c|c|c|c|c|c|}
\hline Tank \# & Capactty & contents & Pushed & Vented & Suminary from Clted sources & Orawing $\#$ \\
\hline 233 & $320 \mathrm{~L}$ & $47 \mathrm{~g} \mathrm{Pu}$ & Y & $Y$ & $\begin{array}{l}\text { Critically safe slab tank made of } 304 \mathrm{~L} \\
\text { stainless steel and used as a Pu Solution } \\
\text { Storage Tank. Installed in } 86 / 87 \text { as part } \\
\text { of project } 0-370 \text {. }\end{array}$ & $\begin{array}{l}\text { H-2-96024, } \\
\text { Rev 1, Sht 2; } \\
\text { H-2-96050, } \\
\text { Rev 1. Sht 1 }\end{array}$ \\
\hline 234 & $156 \mathrm{~L}$ & $33 \mathrm{~g} \mathrm{Pu}$ & $Y$ & $Y$ & $\begin{array}{l}\text { Critically safe slab tank made of } 304 \mathrm{~L} \\
\text { stainless steel and used as a Pu Solution } \\
\text { Storage Tank. Installed in } 86 / 87 \text { as part } \\
\text { of project D-370. }\end{array}$ & $\begin{array}{l}\text { H-2-96024, } \\
\text { Rev 1. Sht 2; } \\
\text { H-2-96051, } \\
\text { Rev 1. Sht 1 }\end{array}$ \\
\hline 235 & $156 \mathrm{~L}$ & $3 \mathrm{gPu}$ & $Y$ & Y & $\begin{array}{l}\text { Critically safe slab tank made of } 304 \mathrm{~L} \\
\text { stainless steel and used as a Pu Solution } \\
\text { Storage Tank. Installed in } 86 / 87 \text { as part } \\
\text { of project } 0-370 .\end{array}$ & $\begin{array}{l}\text { H-2-96024, } \\
\text { Rev 1, Sht 2; } \\
\text { H-2-96051, } \\
\text { Rev 1. Sht 1 }\end{array}$ \\
\hline
\end{tabular}

$\omega$

Flushing: Status report (PNL 1987) addresses the tanks by system rather than individually, the individual tank status was obtained from Harold VanTuyl. There is also general discussion of flushing status in Removal of the Criticality A7arm System From the 209-E Building.

"Most plutonium is residual in permanently installed tanks in the CAR and Mix Rooms. The tanks have been flushed and dried out, so no accountable amount of plutonium is mobile in the tanks."

"--." These items indicate where data was not available from the Status Report for Hanford's critical Mass Laboratory or discussion with the former facility manager. 


\begin{tabular}{|c|c|c|c|c|c|c|}
\hline Tank\# & Capacity & Gontents & Hushed & Vented & Suminary grom G tred Sources. & Orawh ng \# \\
\hline & $320 \mathrm{~L}$ & $47 \mathrm{~g} \mathrm{Pu}$ & Y & $Y$ & $\begin{array}{l}\text { Critically safe slab tank made of } 304 \mathrm{~L} \\
\text { stainless steel and used as a Pu Solution } \\
\text { Storage Tank. Installed in } 86 / 87 \text { as part } \\
\text { of project D-370. }\end{array}$ & $\begin{array}{l}\text { H-2-96024, } \\
\text { Rev 1, Sht 2; } \\
\text { H-2-96050, } \\
\text { Rev 1, Sht } 1\end{array}$ \\
\hline 234 & $156 \mathrm{~L}$ & $33 \mathrm{~g} \mathrm{Pu}$ & Y & Y & $\begin{array}{l}\text { Critically safe slab tank made of } 304 \mathrm{~L} \\
\text { stainless steel and used as a Pu Solution } \\
\text { Storage Tank. Installed in } 86 / 87 \text { as part } \\
\text { of project D- } 370 \text {. }\end{array}$ & $\begin{array}{l}\text { H-2-96024, } \\
\text { Rev 1. Sht 2; } \\
\text { H-2-96051, } \\
\text { Rev 1. Sht 1 }\end{array}$ \\
\hline 235 & $156 \mathrm{~L}$ & $3 \mathrm{~g} \mathrm{Pu}$ & $Y$ & Y & $\begin{array}{l}\text { Critically safe slab tank made of } 304 \mathrm{~L} \\
\text { stainless steel and used as a Pu Solution } \\
\text { Storage Tank. Installed in } 86 / 87 \text { as part } \\
\text { of project } 0-370 \text {. }\end{array}$ & $\begin{array}{l}\text { H-2-96024, } \\
\text { Rev 1. Sht 2; } \\
\text { H-2-96051, } \\
\text { Rev 1. Sht } 1\end{array}$ \\
\hline
\end{tabular}

Flushing: Status report (PNL 1987) addresses the tanks by system rather than individually, the individual tank status was obtained from Harold VanTuyl. There is also general discussion of flushing status in Removal of the Critica7ity A7arm System From the 209-E Building. "Most plutonium is residual in permanently installed tanks in the CAR and Mix Rooms. The tanks have been flushed and dried out, so no accountable amount of plutonium is mobile in the tanks."

" -..". These items indicate where data was not available from the Status Report for Hanford's Critical Mass Laboratory or discussion with the former facility manager. 
HNF-3337, Rev. 0

\section{APPENDIX B}

\section{PURPOSE:}

This section of Appendix $B$ addresses any potential chemical vulnerabilities at the 209-E Building that might lead to a tank explosion.

\section{DISCUSSION:}

Critical mass experiments were mostly carried out using plutonium and uranium solutions. The solution handling system comprised of 12 tanks included TK101. TK-102, TK-103, TK-104. TK-105, and TK-106 located in the Critical Assembly Room and TK-213. TK-231, TK-232, TK-233, TK-234, and TK-235 located in the Mix Room. Other than nuclear poisons (e.g., boron, cadmium, and gadolinium), no other chemicals were added to the system for purposes of valance adjustments or chemical separations. Plutonium in the solutions of plutonium nitrate used in the system would have existed in the +4 and +6 valence states depending on the nitric acid concentration. Normally, the plutonium would be in the +4 valence state but would oxidize to plutonium $(+6)$ at acidities below 4 molar. Once the solution handling tanks were emptied of concentrated material during facility deactivation. flushing of residual heel with process condensate would have created conditions ideal for forming plutonium polymer $\left[\mathrm{PuO}_{2}\left(\mathrm{H}_{2} \mathrm{O}\right)_{7,3}\right]$. Under conditions of transient instability, as in water dilution. plutonium $(+4)$ hydrolyzes readily to form highly insoluble plutonium $(+4)$ hydroxide. Depolymerization becomes more difficult with age and does not readily occur at standard conditions when the acidity is increased. Subsequent purging of the tanks with an air sweep to evaporate most or a 71 of the residual liquid would cause acidity to increase which would likely have only a minor effect on plutonium polymer formed during the tank flush. Residual soluble plutonium would concentrate as drying continued until solubility limits are reached; approximately 2.5 moles/L for plutonium $(+4)$. Further evaporation would result in precipitation of plutonium nitrate. The current state of the residual material in the solution handling tanks, therefore, is likely a mixture of plutonium polymer, plutonium nitrate precipitate, water, nitrate ion, and plutonium ions. These constituents are common to contamination found in hoods, glove boxes, or equipment utilized in fissile material handling operations.

Heterogeneous systems were also tested in the 209-E Critical Mass Laboratory. but did not involve use of the solution handling system. Solid forms of fissile materials and compacts such as plutonium oxide-polyethylene blocks were sealed or canned for contamination control during testing. Discrete 
HNF-3337, Rev. 0

APPENDIX B (cont.)

containers holding solutions were also tested. These systems were tested using the Remote Split-Table Assembly Machine (RSTM) installed in hood H0-170 or the Fuel Element Array System (FEAS) installed in TK-108. Although some of these fuel sources remain in the Critical Assembly Room, they do not constitute a chemical vulnerability because of their stable containerized or encapsulated-solid form.

CONCLUSION:

No chemical vulnerabilities are associated with the material in its current condition. 


\section{HNF-3337, Rev. 0}

APPENDIX B (cont.)

\section{PURPOSE:}

This section of Appendix B provides the calculation for worst case hydrogen $\left(\mathrm{H}_{2}\right)$ generation rates at the 209-E Building. The hydrogen generation rate provides a baseline for determining controls necessary to prevent explosive concentrations in the tanks at the 209-E Building.

\section{DISCUSSION:}

In the Critical Assembly Room (CAR) and Mix Room at the 209-E Building, the highest plutonium (Pu) residual inventory is located at TK-106 (west wall of CAR), which contains 123 grams of Pu with overal1 estimated error of $35 \%$ (PNL 1989b). The analysis is based on tank TK-106 containing 170 grams of ${ }^{239} \mathrm{Pu}$ as a conservative approach. The analysis assumes pure water radiolysis is the only source to generate hydrogen gas. The calculated hydrogen generation rate for the given system is $2.18 \mathrm{E}-05 \mathrm{~L} / \mathrm{min}$, using the methodology of LMHC 1997.

\section{CONCLUSION:}

Calculations show that it takes 115 days to reach $25 \%$ of the lower flammability limit (LFL) for hydrogen in air from an initial steady state concentration $\left(0.005 \% \mathrm{H}_{2}\right)$ when active ventilation is lost. The tank will reach the LFL of $4.0 \% \mathrm{H}_{2}$ in 470 days.

\section{CALCULATIONS:}

Parameters

Mass of ${ }^{239} \mathrm{Pu}$

$\mathrm{Ci}$ per $\mathrm{kg}$ of ${ }^{239} \mathrm{Pu}$

Watt per $\mathrm{Ci}$ of ${ }^{239} \mathrm{Pu}$

Total Heat Load

Cf from watt to eV/hour

Total eV per hour

Number of $\mathrm{H}_{2}$ per $100 \mathrm{eV}$

Total number of $\mathrm{H}_{2}$ per hour

Hydrogen Generation Rate

Hydrogen Generation Rate at $25^{\circ} \mathrm{C}$ values

0.170

61.3

0.0305

0.318

$2.25 \mathrm{E}+22$

$7.15 \mathrm{E}+21$

0.45

$3.22 E+19$

2.18E-05
Unit

$\mathrm{kg}$

$\mathrm{Ci} / \mathrm{kg}$ watt/Ci watt eV/watt-hour eV/hour $\mathrm{H}_{2} / 100 \mathrm{eV}$

$\mathrm{H}_{2}$ /hour 


\section{HNF-3337, Rev. 0}

\section{Appendix B (cont.)}

Normal Operation

Parameters

Tank volume

Tank Headspace (assuming 1/10 ful1)

Hydrogen equivalent concentration of LFL

Hydrogen equivalent concentration of $25 \% \mathrm{LFL}$

- Ventilation rate per tank design specification

-Steady state $\mathrm{H}_{2}$ concentration

$\begin{array}{ll}\text { Values } & \text { Unit } \\ 400 & L \\ 360 & L \\ 4 & \% \\ 1 & \% \\ 0.45 & L / \text { min } \\ 0.005 & \%\end{array}$

Without Active Ventilation System Operating

Time to reach 25\% LFL (initial is 50 ppm $\mathrm{H}_{2}$ )

Time to reach LFL (initial is $50 \mathrm{ppm} \mathrm{H}_{2}$ )

Minimum ventilation rate keeping tank

below 25\% LFL

115

day

470

day

Minimum ventilation rate keeping tank.

$2.16 \mathrm{E}-03^{\circ} \mathrm{L} / \mathrm{min}$ below LFL

5.23E-04 L/min

Note: For a tank volume of $400 \mathrm{~L}$, radiolysis of $12 \mathrm{ml}$ of water is sufficient to reach the LFL.

CALCULATIONS PREPARED BY: A. HU

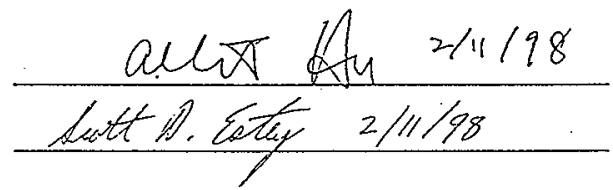

CALCULATIONS REVIEWED BY: 